\title{
CERBE
}

Center for Relationship Banking and Economics Working Paper Series

\section{Family firms and access to credit. Is family ownership beneficial?}

Pierluigi Murro and

Valentina Peruzzi

\section{Working Paper No. 23}

\section{October 2017}

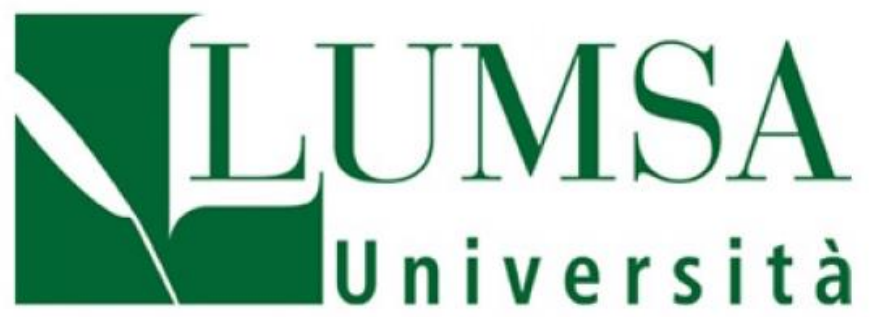

Center for Relationship Banking and Economics Department of Economic and Political Sciences and of Modern Languages LUMSA University

Via Pompeo Magno, 22, 00192 Rome - Italy https://sites.google.com/site/cerbelumsa/home

(C) P. Murro and V. Peruzzi. The aim of the series is to diffuse the research conducted by CERBE Fellows. The series accepts external contributions whose topics are related to the research fields of the Center. The views expressed in the articles are those of the authors and cannot be attributed to CERBE 


\title{
Family firms and access to credit. Is family ownership beneficial?
}

\author{
Pierluigi Murro $^{\S^{*}}$ Valentina Peruzzi $^{\dagger}$ \\ § LUMSA University and CERBE, p.murro@lumsa.it \\ †Polytechnic University of Marche and MoFiR, v.peruzzi@ univpm.it
}

\begin{abstract}
This paper investigates the effect of family ownership on credit rationing using a rich sample of Italian manufacturing firms. We find that family ownership increases the probability of credit rationing. Conflicts between large and minority shareholders, family firms' lack of competencies and conservatism appear to be the main determinants of this result. By contrast, family owners' long-termism, risk aversion, and relational capital mitigate the adverse impact of family ownership on firms' credit availability. Finally, we find that family businesses are more likely to be rationed in provinces with high level of social capital and judicial efficiency, suggesting that delegation problems are mitigated by personal relationships in areas where cooperation mechanisms are weaker.
\end{abstract}

Keywords: Family firms, credit rationing, agency conflicts, relationship lending

JEL codes: D22, G21, G32

\footnotetext{
* Corresponding author. E-mail: p.murro@lumsa.it . Phone: +39 06 68422489. Address: LUMSA University, Via Pompeo Magno 22, 00192 Rome, Italy. We wish to thank seminar and conference participants at the $6^{\text {th }}$ International Conference of the Financial Engineering and Banking Society (Malaga, Spain), the $8^{\text {th }}$ International Workshop on Cooperative Finance and Sustainable Development (Trento, Italy) and LUMSA University (Rome, Italy) for helpful comments and conversations. All remaining errors are ours.
} 


\section{Introduction}

Families have always been at the heart of business (The Economist, 2015). History is full of examples of spectacular ascents of family firms, and even today a large fraction of companies throughout the world are organized around families (Bertrand and Schoar, 2006). Family ownership is widespread among both privately held and publicly traded firms. In Continental Europe, they account for 85 percent of listed companies, but also in the United States and the United Kingdom some of the largest publicly traded firms are controlled by families (La Porta et al., 1999; Faccio and Lang, 2002; Burkart et al., 2003). Because of their diffusion and economic relevance, recently a growing body of literature has focused on family businesses, looking at their performance (Anderson and Reeb, 2003; Villalonga and Amit, 2006; Sraer and Thesmar, 2007), inheritance decisions (Cucculelli and Micucci, 2008; Ellul et al., 2010), and investment policies (Minetti et al., 2015a, Minetti et al., 2015b).

Given the significant impact that family firms' financing could have on the real economy, some empirical works have also analyzed the credit availability of family owned businesses. However, the literature on this topic is still scarce and does not reach clear conclusions. On the one hand, some empirical studies show that family firms, as perceived to be riskier, are significantly associated with higher collateral requirements and deeper screening methods when they relate with the banking system (Voordeckers and Steijvers, 2006; Steijvers et al., 2010; Pan and Tian, 2016; Cucculelli and Peruzzi, 2017). On the other hand, due to the lower incentives for strategic default, family ownership is found to improve firms' credit availability and loan interest rates during the recent financial crisis (D'Aurizio et al., 2015; Stacchini and Degasperi, 2015). The described evidence reflects two opposite views on family firms (Burkart et al., 2003; Bertrand and Schoar, 2006; Minetti et al., 2015b). The efficiency-based view, which considers family ownership as a source of comparative advantage because of family owners' long termism and relational capital, and the cultural view, according to which family firms' lack of competencies, conservatism and agency conflicts may significantly reduce firm value.

In order to contribute to this strand of literature, in this paper we analyze whether family firms differ from non-family ones in the probability of experiencing credit restrictions and investigate which channels affect the ownership-credit rationing link in a non-crisis period. To address this question, we exploit a very detailed survey of over 18,000 Italian manufacturing 
firms conducted by the banking group UniCredit-Capitalia (Survey on Italian Manufacturing Firms, SIMF). The dataset provides unique information on firms' ownership and governance structure, financial conditions and bank-firm relationships based directly on firms' responses to survey questions. ${ }^{1}$ The same survey has recently been used as a testing ground for other objectives, such as exploring the impact of financial development on firms' innovation (Benfratello et al., 2008), studying the role of credit rationing on firm export decisions (Minetti and Zhu, 2011), and investigating the impact of firm ownership structure on innovation activities (Minetti et al., 2015a).

Estimation results indicate that family firms are associated with a higher probability of experiencing credit restrictions. Controlling for a complete set of qualitative and quantitative observable firm characteristics, which could be correlated with the family business status and able to affect credit availability, we find that family firms are 2 percent more likely to be rationed than non-family firms. The analysis then turns to investigate the mechanisms through which family ownership affects the probability of credit rationing. The possible channels of influence are the agency conflicts, the lack of competencies and the conservatism of family owners, on the positive side, and the long-termism, the risk aversion and the ability to create long lasting lending relationships (relationship lending) of families, on the negative side. Regarding the channels of adverse influence (i.e. factors that increase the probability of rationing), we uncover evidence that family ownership increases the probability of firms experiencing credit restrictions for more concentrated, less competent and more conservative companies. Conversely, by analyzing the beneficial characteristics of family firms, we find that family owners' long-termism, risk aversion, and relationship lending mitigate the adverse impact of family ownership on firms' credit availability. Finally, by studying the role of socio-economic conditions on the link between family ownership and credit rationing, we find that family firms are more likely to be rationed in provinces with high level of social capital and judicial efficiency, suggesting that delegation problems are mitigated by personal relationships in areas where cooperation mechanisms are weaker due to lack of trust. However, this does not result in a better access to credit for family owned firms, but in a

\footnotetext{
${ }^{1}$ We use four waves of the survey, which cover the period 1995-2006. The main reasons of using this limited time span is that we aim at focusing on family firms' credit availability during a non-crisis period. In fact, the current literature mainly concentrates on the last financial crisis and the mechanisms affecting the access to credit of family businesses may be different in normal times.
} 
non-significant difference between family and non-family businesses in terms of credit availability.

In providing this evidence, we contribute to the current literature in several ways. First, to the best of our knowledge, this is the first study analyzing family firms' credit rationing in a period of positive economic growth. In this way, we complement the recent findings of $\mathrm{D}^{\prime}$ Aurizio et al. (2015) and Stacchini and Degasperi (2015) focusing on family firms' financial conditions during the recent financial crisis. Second, by trying to disentangle the family ownership - credit rationing link, we provide additional evidence about the advantages and disadvantages of family owners. More precisely, we are the first considering the role of family firms' lack of competencies, conservatism, and relational capital in the analysis of family firms' credit rationing. Moreover, we confirm the adverse impact of family ownership concentration on access to finance, as previously highlighted by Andres (2011), Pindado et al. (2011) and Peruzzi (2017). Finally, by analyzing the role of local socio-economic conditions on family firms' credit rationing, we complement the findings provided by Stacchini and Degasperi (2015) with respect to the cost of credit.

The remainder of the paper is organized as follows. Section 2 describes the institutional background. Section 3 reviews the current literature and develops the testable hypotheses. Section 4 describes the dataset and econometric specification adopted. Section 5 discusses the empirical results, and Section 6 concludes.

\section{Institutional background}

Italy provides an ideal environment to study the credit availability of family firms. First, family ownership plays a key role in this country. According to the last available Census data, in 2011 Italian companies were controlled by an individual or a family in 89 percent of cases, by a financial holding in 10.9 percent of cases, and by a public entity in less than 1 percent of cases. Similar figures characterized the Italian system also in 2001, roughly the middle year of our sample (see Minetti et al., 2015b). Italian firms also exhibit pronounced ownership concentration (Bianco, 2003; Bianchi and Bianco, 2008). This feature is likely to be relevant in the determination of agency conflicts between main owners and minority shareholders, which could be detrimental to firm's creditworthiness and reliability (Claessens et al., 2002). 
Second, as the Italian business sector consists mainly of small and medium-sized businesses, investments are primarily financed through bank loans. ${ }^{2}$ The central role of banks also depends on the long-lasting tradition of cooperative local financial institutions (Gambini and Zazzaro, 2013). According to World Bank data, in 2011 the stock market capitalization (as percentage of the gross domestic product) was almost 18 percent in Italy, compared to 100 percent in the United States (World Bank, 2011; Minetti et al., 2017). In this context, banking relations are at the heart of the financial life of many Italian companies, and analyzing the extent of credit rationing for family owned firms results to be of the outmost importance.

The central role of banks and the widespread diffusion of small and medium-sized family businesses makes the Italian financial and industrial structure close to that of other continental Europe countries, such as France and Germany (Minetti et al., 2015b). Hence, the conclusions reached in this paper may be easily extended to these contexts as well.

\section{Related literature and theoretical predictions}

Although bank lending is the main source of external financing for the majority of family firms, the literature on the impact of family ownership on firms' access to credit is scarce and does not reach univocal results. Finance studies have investigated the existence of family firms' financing constraints through the analysis of their investment-cash flow dependence. However, while Andres (2011) and Pindado et al. (2011) indicate that publicly traded European family businesses have easier access to external financing as showed by the lower investment-cash flow sensitivity, Gugler (2003), Hung and Kuo (2011) and Peruzzi (2017) find completely opposite results. By analysing a sample of Austrian firms, Gugler (2003) shows that family firms suffer from cash constraints as evidenced by a positive and robust relationship of investment to cash flow. Similarly, Hung and Kuo (2011) find that publicly traded Taiwanese family businesses, because of asymmetric information problems, have high investment-cash flow sensitivity than non-family owned firms. Finally, Peruzzi (2017), for a sample of Italian small- and medium-sized enterprises, indicates that family ownership positively affects firms' investment-cash flow dependence, especially when family ownership is highly concentrated.

\footnotetext{
${ }^{2}$ In 2011, companies with less than 20 employees represented more than 90 percent of manufacturing firms.
} 
The banking literature has not been more conclusive. Bopaiah (1998) analyses the availability and cost of trade credit for a sample of US enterprises included in the National Survey of Small Business Finance (NSSBF) and finds that family firms have better access to credit when compared to non-family owned businesses. Similarly, and more recently, D'Aurizio et al. (2015) document that after the Lehman Brother collapse, bank lending to Italian family businesses contracted significantly less than the amount of credit granted to non-family firms. Stacchini and Degasperi (2015) further confirm the beneficial role of family ownership during the financial crisis period. By analysing a sample of Italian companies included in the EU-EFIGE survey, they find that in 2007-2009 family firms have been associated with a significant interest discount. By using the same survey for a sample of European firms, Cucculelli et al. (2016) show that family firms appointing family CEOs enjoy longer-lasting and closer lending relationships in comparison to non-family businesses. However, despite these relevant ties, they are not associated with a better access to bank credit. Contradictory findings have been shown by Voordeckers and Steijvers (2006), Steijvers et al. (2010), Pan and Tian (2016) and Cucculelli and Peruzzi (2017). By analysing family firms' lending relationships, these studies suggest that family ownership positively affects the probability of pledging higher levels of collateral guarantees and being subject to deep screening processes when the firm tries to access the bank lending market.

The controversial evidence about the impact of family ownership on credit availability reflects two opposite theories on family firms (Burkart et al., 2003; Bertrand and Schoar, 2006; Minetti et al., 2015b): the efficiency-based theory, which views family ownership as a source of comparative advantage because of family owners' long termism and relational capital; and the cultural theory, according to which family firms' lack of competencies, conservatism and agency conflicts may significantly reduce firm value. Starting with the negative side of family firms, one of the major problems of family ownership are agency conflicts. Although family businesses often solve the classic owner-manager agency problem, family owned firms are more likely to experience conflicts between controlling and minority shareholders (Villalonga and Amit, 2006; Pindado et al., 2011; Peruzzi, 2017). These problems arise mainly from the risk of wealth expropriation of minority shareholders by the owner family, who may maximize the family's utility rather than firm value with adverse consequences on external investors' interests and the firm's access to credit. According to the literature, family owners may also lack the competencies 
necessary to efficiently run a business, thus increasing the probability of firms experiencing credit restrictions (Perez-Gonzalez, 2006; Bennedsen et al., 2007). Finally, worries about firm survival and intentions to preserve the status quo lead family owners to promote conservative strategies (Daily and Dollinger, 1992; Habbershon et al., 2003; Miller et al., 2008). This tendency to conservatively preserve their position, which significantly reduce family firms' growth opportunities (Poza et al., 1997; Allio, 2004), may be negatively evaluated by lenders, thus making family businesses more likely to face financing constraints.

In contrast with this negative view of family ownership, several studies highlighted a set of advantages of family-owned firms. First, according to the theoretical literature, family businesses are characterized by a long-term horizon. The links between current and future generations provide family firms with "patient capital", a focus on maximizing long-run returns, and the desire to pursue investment opportunities that myopic non-family firms would not (Bertrand and Schoar, 2006). The presence of shareholders with longer investment horizons increases investment efficiency and reduces the agency conflicts in the shareholder-bondholder relationship, thus mitigating external financing constraints (Stein, 1988; 1989; Wang, 2006; Morgado and Pindado, 2003; Pindado et al., 2011). The desire to transfer the firm down to future generations and protect the reputation acquired thanks to the identification of the family name with the firm make family owners more risk averse and less likely to strategically default (Anderson et al., 2003; Anderson et al., 2012; D'Aurizio et al., 2015). The higher risk aversion of family owners increases loan repayment probabilities and translates in better credit availability for family owned businesses. Finally, as shown by the current literature (Salvato and Melin, 2008; Faccio and Parsley, 2009; Amore and Bennedsen, 2013; Bunkanwanicha et al., 2013), family firms invest large amounts of resources in nurturing interpersonal relations and building webs of business contacts with competitors, customers, and politicians, which improve the firm's economic performance. Among the web of relationships family firms may invest in, there is the one with their lenders, which should provide better access to credit and lower rationing probabilities for family owned businesses (Cucculelli et al., 2016).

Consistently with these contrasting theories, we test the following hypothesis: 
Hypothesis 1: When the cost of family firms' agency conflicts, limited skills and conservatism prevail over the benefit of their long-term horizon, risk aversion and relational capital, family firms are more likely to experience credit rationing than non-family owned firms.

As suggested by the economic literature, where cooperation mechanisms are weaker due to the lack of social capital, delegation problems and other agency conflicts are mitigated by personal relationships, such as those built by family members (Putnam, 1993; Fukuyama, 1995). Stacchini and Degasperi (2015) verify the implications of this theory and find that family ownership reduces the agency cost of debt in local markets characterized by low levels of social capital and trust. Where the tendency to cooperate is weaker and individuals are more inclined to behave opportunistically, borrowers are more likely to invest in risky projects without bearing the costs of downside failure. In this context, the advantages of family ownership should outweigh their disadvantages, thus improving family firms' access to credit. Consistently with this view, we formulate our second hypothesis as follows:

Hypothesis 2: In regions with low levels of social capital, family firms are less likely to experience credit rationing than non-family owned firms.

\section{Data and empirical method}

\subsection{Data sources}

To test our hypotheses, we draw information from two main sources: (i) the Survey on Italian Manufacturing Firms, carried out by the banking group UniCredit (and previously by MedioCredito Centrale - Capitalia); and (ii) the BvD-AIDA database.

The Survey on Italian Manufacturing Firms (SIMF) provides detailed information about companies' ownership and governance structure, export and internationalization activities, investments in innovation and $\mathrm{R} \& \mathrm{D}$ expenditure, workforce characteristics and bank-firm relationships. The dataset includes a representative sample of manufacturing companies with 10-500 employees (about 94 percent of the sample) and the universe of manufacturing firms with 
more than 500 employees. ${ }^{3}$ We use four waves of the survey covering the three-year periods 1995-1997, 1998-2000, 2001-2003 and 2004-2006. Each of the waves gathers information on approximately 4500 firms, representing about 9 percent of the population in terms of employees and 10 percent in terms of value added. For all the surveyed firms, we attach balance-sheet information provided by BvD-AIDA, the most comprehensive source of financial information for Italian companies.

To complement the survey, we use data about the value added and population of Italian provinces provided by the Italian National Statistics Office (ISTAT), the number of bank branches in local markets recovered from the Bank of Italy, and the index of external financial dependence developed by Rajan and Zingales (1998).

Table 1 provides a detailed description of all the variables employed in the empirical analysis, while Table 2 reports summary statistics (for all firms, by ownership structure and rationing status). At the average, the surveyed firms have been in business for 26 years; beyond 50 percent of them have fewer than 40 employees (below 5 percent of the firms have more than 500 workers); 30 percent of them operate in high-tech sectors. Moving on to their financial setup, on average firms do business with five banks and the average length of the relationship with the main bank is 16 years. The firms are largely located in the north of Italy (68 percent of the total), while 18 percent of the companies are in the center and 14 percent are in the south.

\subsection{Variable definitions}

\subsubsection{Credit rationing}

Our measures of credit rationing are directly taken from the following questions of the Survey on Italian Manufacturing Firms: (i) "In the last year, would the firm have liked to obtain more credit at the market interest rate?"; (ii) "In the last year, did the firm demand more credit than it actually obtained?'. Given companies' answers and following Minetti and Zhu (2011), we define weak rationed firms as those that gave a positive response to question (i), regardless of their answer to question (ii), and strong rationed companies as those that responded "yes" to both questions. Firms classified as weakly rationed but not strongly rationed can be both firms discouraged from applying for credit and firms that are requested an interest rate higher than the market rate. Both

\footnotetext{
${ }^{3}$ Firms with 10-500 employees are selected with a stratified sampling method each time with a rotating panel scheme; therefore, only few of them appear in two consecutive waves.
} 
measures, although reflecting a different intensity of rationing, should capture the existence of credit constraints.

Summary statistics reported in Table 2 indicate that, in the whole sample, only 3.69 percent of firms are strongly rationed, whereas 13.23 percent of companies result to be weakly rationed. Figure 1 draws the distribution of credit rationed firms across provinces. The figure indicates that rationed firms are not clustered in few provinces. Although companies in Southern provinces are more likely to be rationed overall, we still find that some Northern provinces have a relatively high share of rationed firms. On the other hand, some Southern provinces have a relatively low share of rationed businesses.

Our data are consistent with those obtained by other studies analyzing the credit rationing phenomenon. Using the EFIGE Survey, Ferri et al. (2017) find that in 2007-2009 about 4.4 percent of Italian firms suffered from strong rationing, and this figure rises to 12.6 percent when discouraged borrowers are included. Outside the Italian context, Levenson and Willard (2000), using the 1987-1988 wave of the National Survey of Small Business Finances (NSSBF), find that 4.3 percent of firms were turned down when they applied for credit and 8.52 percent of companies were weakly rationed.

\subsubsection{Family ownership}

To distinguish between family and non-family owned companies, in this study we rely on firms' self-reported information. The Survey on Italian Manufacturing Firms asks each firm to indicate the characteristics of the main shareholders of the firm, such as their types and equity shares. Hence, our main measure of family ownership (Family firm) is a binary variable that is equal to one if the main shareholder is an individual or a family, and zero otherwise. As robustness checks, we employ two additional definitions of family firms: (i) Family Control, a dummy variable equal to one if the main shareholder is a family or an individual and he has direct control over the firm, and zero otherwise; (ii) Family Firm 20\%, a dummy variable equal to one if the main shareholder is a family or an individual and he owns more than 20 percent of the company, and zero otherwise.

The data confirm the relevance of family firms in the Italian manufacturing sector: in our sample, almost 80 percent of firms are family owned. The summary statistics reported in Table 2 further inform us about the alignment between ownership and control and between ownership and management: in our sample, 93 percent of family owners have control rights (Family Control, 72.2 
percent of the surveyed firms), and 66 percent of family businesses are run by family members (External Manager, 48.8 percent of the surveyed firms).

\subsubsection{Control variables}

To correctly identify the impact of family ownership on firms' access to credit and to mitigate the omitted variables concern associated with the cross-sectional structure of our dataset, we control for a large set of possible confounding effects. First, we consider the following standard firm-specific characteristics and balance-sheet indicators: (i) the number of employees as proxy for firm's size (Size, expressed in logarithm); (ii) firm's age, measured by the number of years from its inception (Age); (iii) the level of indebtedness, proxied by the leverage indicator (Leverage, computed as total debt over equity); (iv) the return on investments (ROI); (v) the company's labour productivity (Labour productivity, measured by value added per worker); (vi) the firm's capital intensity (Capital intensity, computed as the ratio between firm's fixed assets and number of employees); (vii) the ownership share of the first shareholder (Ownership concentration). Second, we control for a number of bank-firm relationship characteristics, by including the number of bank relationships enjoyed by the firm (Number of banks), and the length of the main bank-firm relationship (Relationship Length). Third, we include a set of provincial indicators: the growth rate of value added (Value added), and the Herfindahl index of the bank branches (HHI). Then, to account for the different degree of dependence of industrial sectors on external source of finance, we add the index of external financial dependence developed by Rajan and Zingales (1998). Finally, in order to fully account for industry- and regional-specific effects, we include geographical and industry dummies.

\subsection{Econometric specification}

To test our hypotheses, we start building an empirical model that estimates the probability of firms being rationed in the bank lending market. Define $y_{i}^{d}$ as firm $i$ 's desired amount of credit and $y_{i}^{a}$ as the actual credit given to firm $i$, the firm is rationed any time $y_{i}^{*}=\left(y_{i}^{d}-y_{i}^{a}\right)>0$.

Thus, we can model the probability of rationing as:

$$
y_{i}=\left\{\begin{array}{cc}
1 & \text { if } y_{i}^{*}>0 \\
0 & \text { otherwise }
\end{array}\right.
$$




$$
y_{i}^{*}=\alpha X_{i}+\beta Z_{i}+u_{i}
$$

where $y_{i}$ denotes, alternatively, one of the credit rationing indicators described in section 4.2.1, i.e. Weak Rationing and Strong Rationing; $X_{i}$ is the measure of firm $i$ 's ownership structure presented in section $4.2 .2 ; Z_{i}$ is a vector of exogenous covariates; $u_{i}$ is the residual. ${ }^{4}$

\section{Results}

\subsection{Baseline results}

Table 3 shows Probit regressions of the likelihood of weak (columns 1-3) and strong rationing (columns 4-6). In columns (1) and (4) we report the results for our main measure of family ownership (Family Firm). In the other columns, as a robustness check, we use the two alternative proxies of family ownership (Family Control and Family Firm 20\%), as described in section 4.2.2. We find that after controlling for various firm characteristics and province fixed effects, family firms are 2 percent more likely to be weak credit rationed than non-family firms (statistically significant at 99 percent; column 1). The results are very similar when we consider family control as proxy of family ownership and when we restrict the definition of family firms to those companies whose family owners own more than 20 percent. The estimated marginal effects are, respectively, 0.022 (statistically significant at 99 percent; column 2) and 0.013 (statistically significant at 90 percent; column 3). The coefficients are smaller, but still significant, for strong rationing (column 4-6): family firms are 0.8 percent more likely to experience strong credit rationing in comparison to non-family owned firms (statistically significant at 95 percent). ${ }^{5}$

As for the control variables, estimation results indicate that firm size (Size) reduces the probability of experiencing credit restrictions. The marginal effects are -0.026 and -0.006 for weak and strong credit rationing, respectively (both statistically significant at 99 percent). Our measures of profitability (ROI) and productivity (Labour Productivity) are also negatively associated with the credit rationing status. The marginal effects for weak credit rationing are 0.374 and 0.045 for

\footnotetext{
4 As our dependent variables are dummy variables taking values zero and one, we estimate Equation (2) by maximum likelihood probit regressions.

5 The marginal effects for Family Control and Family Firm 20\% are, respectively, 0.007 (statistically significant at 95 percent; column 5) and 0.007 (statistically significant at 90 percent; column 6).
} 
the two variables of interest (both statistically significant at 99 percent). ${ }^{6}$ As expected, financial dependence (measured by the Rajan-Zingales index), leverage and ownership concentration increase the probability of being credit restricted. As reported in column (1), the marginal effects for weak credit rationing are 0.034 (statistically significant at 95 percent), 0.002 (statistically significant at 99 percent) and 0.029 (statistically significant at 95 percent). Regarding the bank-firm relationship characteristics, in line with the current literature, regression results indicate that the number of bank relationships enjoyed by the firm increases the probability of experiencing credit restrictions, while the length of the bank-firm relationship significantly reduces the likelihood of being rationed by banks. The marginal effects for weak credit rationing are 0.006 (statistically significant at 99 percent) and -0.008 (statistically significant at 95 percent), respectively. Finally, as for the characteristics of the local environment, while the Herfindhal-Index on bank branches and provincial value added do not significantly affect the probability of firms being credit rationed, companies located in the north or center of Italy are found to be less likely to experience credit restrictions when compared to companies located in the south.

\subsection{Disentangling the ownership-credit rationing link}

In this section, we test the channels through which family ownership affects the probability of firms being credit rationed by banks. As discussed in the previous sections, the possible channels of influence are the agency conflicts, the lack of competencies and the conservatism of family owners, on the one side, and the long-termism, the risk aversion and the ability to create long lasting lending relationships (relationship lending) of families, on the other side.

\subsubsection{Family ownership and agency conflicts}

Several studies show that the relation between ownership and firm value is nonlinear because of the monitoring and expropriation effects associated with ownership concentration (Gedajlovic and Shapiro, 1998; Thomsen and Pedersen, 2000; Pindado et al., 2011; Minetti et al., 2015b). Although family ownership often solves the classic owner-manager agency problem, family firms may experience higher conflicts between controlling and minority shareholders (Villalonga and Amit,

\footnotetext{
6 The marginal effects for strong credit rationing are -0.230 for firm profitability and -0.012 for labour productivity, both statistically significant at 99 percent.
} 
2006; Pindado et al., 2011; Peruzzi, 2017). This agency problem results mainly from the risk of wealth expropriation of minority shareholders by the owner family. In fact, family owners with large ownership shares may have the incentives and the power to take actions that benefit themselves at the detriment of firm performance and other investors' interests, with adverse consequences on firms' access to external financing. ${ }^{7}$ In Table 4 we investigate whether these problems exacerbate the adverse impact of family ownership on bank credit availability. In particular, in columns (1)-(4) of Table 4 we split the sample based on the distribution of the first shareholder's ownership share. The results indicate that family ownership positively affects the probability of experiencing credit restrictions for the subsamples of firms with dispersed (column 1) and highly concentrated ownership (column 4), whereas it is not statistically significant in the other cases. More specifically, while family firms with dispersed ownership are 3.2 (0.9) percent more likely to be weak (strong) rationed by banks (statistically significant at 90 percent), highly concentrated family ownership increases the probability of weak (strong) credit rationing by 2.3 (1.8) percent (statistically significant at 90 and 95 percent, respectively).

La Porta et al. (1999) argue that large shareholders in companies with concentrated ownership may monitor each other and subsequent studies show that firm value increases when firms have a second large shareholder because of his ability to monitor and contest the largest owner (Jara-Bertin et al., 2008; Maury and Pajuste, 2005; Pindado et al., 2011). If the disciplining role exercised by other large investors leads family firms to invest more efficiently, family businesses with a second blockholder should be less likely to experience credit rationing. Hence, in columns (5)-(6) of Table 4 we classify firms according to the presence of a second large blockholder, i.e. a second shareholder with more than 25 percent of ownership. The marginal effects indicate that family firms are 2.8 (1.6) percent more likely to be weak (strong) credit rationed (statistically significant at 95 and 99 percent, respectively) when there is not a second large blockholder who may monitor family owners' initiatives. Conversely, family businesses characterized by the presence of a second large shareholder are not significantly different from non-family firms in terms of access to credit. This result confirms the adverse impact of ownership concentration on the probability of family firms experiencing credit restrictions. When the discretion of the controlling family to act in its own best interest is high, expropriation of minority

\footnotetext{
${ }^{7}$ For instance, family owners may take investment decisions that are inefficient for minority shareholders but beneficial for the owning family (Anderson and Reeb, 2003; Pindado et al., 2011).
} 
investors' wealth is more likely to occur with a consequent increase in the probability of being credit rationed.

\subsubsection{Family ownership, lack of competencies and conservatism}

A second channel through which family ownership may adversely affect firm's access to credit is the shortage of skills of family owners. As highlighted by the current literature (Perez-Gonzalez, 2006; Villalonga and Amit, 2006; Bennedsen et al., 2007), family owners may lack the competencies necessary to efficiently run a business thus significantly increasing the probability of firms experiencing credit restrictions. Following Minetti et al. (2015b), we test the validity of this channel in two ways. First, we analyze whether the positive impact of family owners on the probability of being credit rationed is stronger in sectors and markets characterized by a higher level of sophistication and complexity. For this purpose, in columns (1)-(2) of Table 5, we split the sample in Traditional and Non-Traditional (Scale-intensive; Specialized; High-tech) industries according to the Pavitt taxonomy (Pavitt, 1984) ${ }^{8}$ The results show that the positive impact of family ownership on the probability of being rationed is stronger the higher the degree of sophistication and technological content in the industry. More specifically, family firms operating in non-traditional sectors are 2 percent more likely to experience weak credit rationing than non-family owned firms (statistically significant at 90 percent). Conversely, family businesses operating in traditional industries, where the level of sophistication and complexity is lower, are not statistically different from non-family firms in terms of access to credit. Second, as an unskilled workforce could particularly hinder the productivity of family firms and could exacerbate the limited competencies of family owners, we check whether the probability of credit rationing is higher for family firms with a less educated and trained workforce. Hence, in columns (3)-(4) of Table 5, firms are classified in High-Skilled Workforce (Low-Skilled Workforce) if the percentage of graduate employees is higher (lower) than the industry median. Marginal effects indicate that family firms with less skilled employees are 2.4 (1.7) percent more likely to be weak (strong)

\footnotetext{
${ }^{8}$ Traditional sectors are characterized by highly standardized processes and established technologies. Scale intensive sectors are characterized by a level of sophistication somewhat higher than traditional industries, as they typically import innovations from external sources but sometimes also develop them internally. Specialized industries have an even higher level of sophistication and technological content: firms in these industries typically produce machinery and software for other industries and their innovations often arise from complex interactions with the users of their products. Finally, High-tech industries feature the highest degree of sophistication, technological content and R\&D intensity (Minetti et al., 2015b).
} 
rationed when compared to non-family firms (statistically significant at 95 and 99 percent, respectively). These results indicate that the positive impact of family ownership on the probability of experiencing credit rationing is higher for firms with a less skilled workforce, suggesting that in these enterprises the potentially limited competencies of family owners are further exacerbated by the lack of skills of their workers.

A large part of the current literature characterizes family owned firms as conservative (Ward, 2004; Bertrand and Schoar, 2006; Miller et al., 2008; Anderson et al., 2012; Minetti et al., 2015a). Worries about family security and intentions to preserve the status quo lead family owners to promote conservative strategies that precludes moving beyond narrow market boundaries (Daily and Dollinger, 1992; Donckels and Frohlich, 1991; Habbershon et al., 2003; Miller et al., 2008). The tendency of family firms to conservatively preserve their position, which significantly reduce growth opportunities (Poza et al., 1997; Allio, 2004), may be negatively evaluated by lenders, thus making family businesses more likely to face financing constraints when compared to non-family owned firms. In columns (5)-(8) of Table 5, we test the validity of the conservatism channel by splitting the sample based on a firm's narrowness (columns 5-6) and size (columns 7-8). First, by arguing that firms operating in more specific sectors are more conservative (Minetti et al., 2015b), we distinguish firms operating in a five-digit ATECO sector and firms active in a three- or four-digit ATECO industry. The estimates reveal that family ownership positively affects the probability of experiencing credit restrictions only for the subsample of more conservative firms (i.e. firms operating in a five-digit ATECO sector). More specifically, family firms operating in a five-digit ATECO sector are 2.8 (1.1) percent more likely to be weak (strong) rationed when compared to non-family owned firms (statistically significant at 95 percent). Conversely, family firms operating in a three- or four-digit ATECO industry are not significantly different from non-family businesses in terms of access to credit. Second, for the purpose of checking this result, we use firm size as proxy for conservative behaviors. Hence, in columns (7)-(8) of Table 5, we test whether family ownership affects the probability of experiencing credit restrictions for SMEs and large firms, separately. ${ }^{9}$ The results indicate that family firms are 3.1 (1.4) percent more likely to face weak (strong) credit rationing than non-family firms when they are of small size. On the contrary, family ownership does not significantly affect the probability of experiencing credit

\footnotetext{
${ }^{9}$ Firms are categorized into SMEs (Large Firms) if the company has less (more) than 250 employees, 50 million euros
} of total sales and 43 million euros of total assets. 
restrictions for the subsample of large companies, suggesting that less conservative family firms are not different from non-family businesses in terms of credit availability.

\subsubsection{Family ownership, long termism and risk aversion}

The success of some family businesses has driven the perception that family owned firms embrace a longer-term approach to management in comparison to widely-held corporations (James, 1999; Anderson and Reeb, 2003; Bertrand and Schoar, 2006). The underlying idea is that the links between current and future generations provide family firms with "patient capital", a focus on maximizing long-run returns, and the desire to pursue investment opportunities that more myopic non-family firms would not (Bertrand and Schoar, 2006). Besides mitigating the incentives for myopic investment decisions, the presence of shareholders with relatively long investment horizons reduces the agency conflicts in the shareholder-bondholder relationship thus decreasing external financing constraints (Stein, 1988; 1989; Wang, 2006; Morgado and Pindado, 2003; Pindado et al., 2011). Capturing the possible long-termism of family owners is a difficult task as the Survey on Italian Manufacturing Firms does not include a precise proxy for the length of firms' horizon. However, as the literature on firm survival indicates that older firms have a higher probability of survival and hence a longer-term horizon (Minetti et al., 2015b), in columns (1)-(2) of Table 6, we split the sample based on firm age. The results show that family ownership positively affects the probability of experiencing credit restrictions for the subsample of younger firms, i.e. those with less than 22 years of operation (the sample median), while it is not statistically significant for companies operating for longer time. ${ }^{10}$ The marginal effects of the Family Firm dummy for the subsample of young firms are 0.033 (statistically significant at 99 percent) and 0.013 (statistically significant at 95 percent) for weak (Panel A) and strong rationing (Panel B), respectively. This result suggests that the positive effect of family ownership on the probability of being credit rationed is somewhat mitigated by the long-termism channel, which makes older family firms not significantly different from non-family owned businesses in terms of access to credit. The stronger impact of family ownership on the probability of experiencing credit restrictions for young firms may also be due to the high level of opacity characterizing young companies, which may adversely affect banks' ability to properly assess their creditworthiness.

10 The results are qualitatively similar when we use 10 years as a threshold to split the sample. 
Hence, to further check the validity of the long-termism channel, in column (3) of Table 6, we use a different proxy for the length of firms' horizon, i.e. the presence of family CEOs. As family managers retain their positions longer than other CEOs, they are usually characterized by longer time horizons, higher long term investments and deeper knowledge of the business (Morck et al., 1989; Huson et al., 2001; Anderson and Reeb, 2003; Le Breton-Miller and Miller, 2006). The last two waves of the Survey on Italian Manufacturing Firms ask each firm whether it is managed by external managers. In column (3) of Table 6, we restrict the analysis to these two waves and examine the impact that outside directors have on the probability of being credit rationed. The marginal effects indicate that family firms with external managers are 2 percent more likely than non-family firms of experiencing weak credit rationing (statistically significant at 95 percent), whereas those without external CEOs are not significantly different from non-family firms in the probability of being credit rationed. This result confirms the idea that the adverse impact of family ownership on firms' credit availability is mitigated by the long-termism of family CEOs and exacerbated by the short-termism of external managers (Pindado et al., 2011).

A second channel through which family ownership may reduce the probability of experiencing credit restrictions is family owners' risk aversion. Burkart et al. (2003) and Bandiera et al. (2015) have observed that family owners attach a non-monetary value to control, as the personal status acquired thanks to the identification of the family name with the firm or the desire to pass the firm on to future generations. These characteristics translate into higher non-monetary costs of default, which reduce the incentive for strategic default and increase loan repayment probabilities (Anderson et al., 2003; Anderson et al., 2012; D'Aurizio et al., 2015). For the purpose of testing this channel, in columns (4)-(7) of Table 6 we split the sample based on a firm's legal status (columns 4-5) and financial portfolio concentration (columns 6-7). First, we allow for differences in the legal structure of the sampled companies by classifying firms in Limited Liability and Unlimited Liability. As shareholders of corporations may be less averse to risk than shareholders of unlimited liability firms, we expect that family ownership reduces the probability of experiencing credit restrictions when family owners are particularly averse to risk, i.e. when they are not protected by limited liability. The results partially support this prediction: family ownership positively affects the probability of being credit rationed for the subsample of firms 
protected by limited liability, ${ }^{11}$ while it is not statistically significant for the subsample of companies with unlimited liability. These findings suggest that the negative effect of family ownership on firms' access to credit is mitigated when family owners are more risk averse. This does not make family businesses less likely to experience credit rationing, but at least makes family firms not statistically different from non-family firms in terms of credit rationing. Second, we classify firms according to their financial portfolio concentration. In fact, if the financial portfolio of a firm is not diversified, large investors could be reluctant to undertake risky projects, being more averse to risk (Bolton and Von-Thadden, 1998). Our measure of financial concentration is based on a survey question asking firms about the allocation of their financial investments, ${ }^{12}$ which allows us to calculate the Herfindahl-Hirschman index (HHI) of the various asset shares. Starting from this measure, we then create the dummy variable Financial Concentration taking the value of one if the HHI of the firms' asset shares is higher than the median value of the companies operating in the same industry, and zero otherwise. Although we expect a negative coefficient for the Family Firm dummy for the subsample of companies characterized by higher risk aversion (i.e. financially concentrated firms), the results are not statistically significant. This may be due to both the suitability of the measure employed and the low rate of response to the question used to build the Financial Concentration dummy, which is about 35 percent.

\subsubsection{Family ownership and relationship lending}

As documented by the current literature, the web of relationships built over time by the family firms' founders and family members are crucial factors in running a firm successfully (Rose, 2000; Braggion, 2011; Alfani and Gourdon, 2012; Colli, 2012; Carillo et al., 2015; Cucculelli et al., 2016). Investing large amounts of resources in nurturing interpersonal relations and building webs of business and political contacts allow family firms to capture public resources, avoid expropriations and improve their economic performance (Salvato and Melin, 2008; Faccio and Parsley, 2009; Amore and Bennedsen, 2013; Bunkanwanicha et al., 2013). A well-established result in the banking literature is that the existence of exclusive and closer lending relationships improves a firm's access to credit and increases its investments (Liberti and Mian, 2009; Uchida et

\footnotetext{
11 Family firms with limited liability are 1.9 (0.8) percent more likely to suffer from weak (strong) credit rationing with respect to limited liability non-family firms (statistically significant at 95 percent).

12 The question distinguishes among equity participation in Italian companies, equity participation in foreign companies, short-term Italian bonds, medium- and long-term Italian bonds, foreign bonds, other financial instruments.
} 
al., 2012; Ferri and Murro, 2015; Cosci et al., 2016; Cucculelli et al., 2016). Hence, among the webs of relationships family firms may invest in, one of the most useful may be the one with their lenders. Coherently with this view, in Table 7, we test whether the impact of family ownership on the probability of experiencing credit restrictions is affected by the existence of stronger lending relationships. Following the banking literature, we measure relationship lending in two different ways (Elsas, 2005; Alessandrini et al., 2008; Presbitero and Zazzaro, 2011; Ferri and Murro, 2015). First, as bank-firm proximity reduces the existence of financing constraints (Alessandrini et al., 2008; Presbitero and Zazzaro, 2011), in columns (1)-(2) of Table 7, firms are categorized as having a Local (Non-Local) Bank if the firm's main bank is (not) located in the same province of the company. Then, following the indication of Elsas (2005), who showed that the bank's share of firm's total debt is significantly associated with the bank being a relationship lender, in columns (3)-(4) of Table 7, we split our sample based on the share of bank credit supplied by the firm's main bank. The results indicate that family firms are 3.4 (2) percent more likely of being weak (strong) credit rationed when they operate with non-local banks (statistically significant at 99 percent), while they are not significantly different in terms of credit availability from non-family businesses when they enjoy closer lending relationships (i.e. when they operate with local banks). Similar results are found when the main bank financing share is used as a proxy for relationship lending. As reported in columns (3)-(4) of Table 7, family ownership positively affects the probability of experiencing credit restrictions only for the subsample of companies with lower main bank financing share. ${ }^{13}$ Conversely, family firms enjoying more exclusive lending relationships, i.e. firms financed by their main banks by more than 30 percent of total debt, are not significantly different from non-family firms in terms of credit rationing, confirming the existence of the relationship lending channel.

\subsection{Family ownership and socio-economic conditions}

In Table 8, we study the role of socio-economic conditions on the link between family ownership and credit rationing. Stacchini and Degasperi (2015) suggest that family firms could have a role in reducing the agency cost of debt in local markets with low levels of social capital and trust. In these areas, market agents are more inclined to behave opportunistically, and borrowers could be more

\footnotetext{
${ }^{13}$ The estimated marginal effects are 0.026 (statistically significant at 99 percent) for weak rationing (Panel A), and 0.009 (statistically significant at 95 percent) for strong rationing (Panel B).
} 
prone to invest in risky projects without considering the costs of failure. Following this idea, in columns (1)-(4) of Table 8, we split the sample based on two measures of social capital (Guiso et al., 2004): blood donations and voter turnout (for the referenda before 1990s). ${ }^{14}$ The results show that family firms are more likely to be rationed in provinces with high levels of social capital, ${ }^{15}$ confirming that delegation problems are mitigated by personal relationships in areas where cooperation mechanisms are weaker due to the lack of trust. However, this does not result in a better access to credit for family owned firms, but in a non-significant difference between family and non-family businesses in terms of credit availability. In columns (5)-(6) of Table 8, we further develop this topic by splitting the sample based on whether firms are located in the North and Center or in the South of Italy ${ }^{16}$. The three Italian macro-regions differ significantly in terms of socio-economic development (D'Onofrio et al., 2017). The North of Italy is the area with the highest levels of per capita GDP and social capital, while the South is poorer and includes those regions with lower levels of social capital and trust (Guiso et al., 2004; Stacchini and Degasperi, 2015). Estimation results indicate that family ownership positively affects the probability of experiencing credit restrictions only in the North and Center of Italy. ${ }^{17}$ Conversely, family firms located in the South are not significantly different from non-family owned businesses in terms of credit availability. This result suggests that family ownership is beneficial in contexts with fragile socio-economic conditions. On the contrary, in more developed regions the negative aspects of family firms result to prevail on their positive effects. Finally, credit rationing could be affected by the verifiability of a firm's output, which in turn depends on the efficiency of the court system (Ferri and Murro, 2015). To measure judicial efficiency we use the number of days provincial courts take to complete a first-degree trial (Guiso et al., 2004). The results reported in columns (7)-(8) of Table 8 confirms our previous findings: family firms are more likely of experiencing credit restrictions when they are located in provinces with high levels of judicial efficiency.

\subsection{Endogeneity of family ownership}

\footnotetext{
14 Social capital and judicial efficiency variables are all computed at the provincial level.

15 Family firms are 2.7 and 3.1 percent more likely to be weak credit rationed in provinces with high levels of blood donations and voter turnout, respectively (statistically significant at 95 and 99 percent).

16 As a robustness check, we also run regression splitting North and Center provinces. Results, available upon request, are qualitatively similar.

17 Family firms located in the North and Center of Italy are 1.9 (0.7) percent more likely of being weak (strong) credit rationed than non-family owned companies (statistically significant at 95 and 90 percent).
} 
The probit estimates discussed in the previous sections might be affected by endogeneity problems. First, financial constraints may trigger changes in firm ownership structure. However, as in our sample family ownership is persistent over time, concerns about reverse causality issue are somewhat reduced. ${ }^{18}$ Second, although in our regressions we control for a large set of factors that may affect credit availability, it is still possible that some unobserved variables simultaneously affect firm ownership and credit rationing. To correct for endogeneity, we employ a Heckman-type selection model (Wooldridge, 2002; Stacchini and Degasperi, 2015). In the selection equation, we estimate the probability of firms being family owned on the set of control variables discussed in Section 4.2.3, as well as the following dummy variables (i.e. exclusion restrictions): (i) Financial Institution Subscriber, equal to one if a financial institution underwrote new shares of the firms in the three-years of the survey, and zero otherwise; (ii) Other Subscriber, equal to one if a non-financial institution underwrote new shares of the firms in the three-years of the survey, and zero otherwise; (iii) Intention to go Public, equal to one if the firm plans to go public in the following year, and zero otherwise. ${ }^{19}$ In the principal equation, we estimate the determinants of credit rationing, including the inverse Mills ratio generated from the selection equation as selectivity correction among the covariates.

In Table 9, we report estimation results of the Heckman model. As expected, financial and non-financial institution subscriptions reduce the probability of firm being family owned, while the firm's intention to go public does not significantly affect the family firm outcome (columns 1-3). Regarding the credit rationing status, the marginal effects reported in columns (4)-(9) broadly confirm our previous findings. All the proxies of family ownership are positively associated with the probability of firms being credit restricted.

\section{Conclusions}

This paper has analyzed the impact of family ownership on the probability of firms experiencing credit restrictions during a non-crisis period. We have found that, controlling for a complete set of qualitative and quantitative observable firm characteristics, family firms are associated with a

\footnotetext{
${ }^{18}$ Minetti et al. (2015b), by employing the same dataset and considering those companies included in all the waves of the Survey on Italian Manufacturing Firms (from 1995 to 2006), find that family ownership is stable for 80 percent of family businesses.

${ }^{19}$ These variables should predict family ownership but not the credit rationing status. Statistical evidence supports our assumption, since the correlation between credit rationing on the one hand and these variables on the other appears to be negligible at $0.0001,0.0082,0.0213$ for weak rationing and $0.0028,0.0181,0.0048$ for strong rationing.
} 
higher probability of being credit rationed when compared to non-family firms. This result is robust to different definitions of family ownership, which include family control and family ownership greater than 20 percent of equity shares. We have also investigated the channels affecting the family ownership-credit rationing link. Following the theoretical literature, we have considered agency conflicts, the lack of competencies and the conservatism of family owners, on the positive side, and the long-termism, the risk aversion and the ability to create long lasting lending relationships (relationship lending) of families, on the negative side. Estimation results have indicated that family ownership increases the probability of firms experiencing credit restrictions for more concentrated, less competent and more conservative companies. Conversely, by analyzing the beneficial characteristics of family firms, we have found that family owners' long-termism, risk aversion, and relationship lending mitigate the adverse impact of family ownership on firms' credit availability. Finally, by studying the role of socio-economic conditions on the link between family ownership and credit rationing, we have shown that family firms are more likely to be rationed in provinces with high level of social capital and judicial efficiency, suggesting that delegation problems are mitigated by personal relationships in areas where cooperation mechanisms are weaker due to lack of trust.

These findings have some policy implications. First, the paper highlights the actions that family firms can implement to mitigate the probability of experiencing credit rationing, such as reducing the level of ownership concentration and conservative strategies, increasing the skills of their workforce and firm size. Second, our results suggest that some policy interventions, like the deployment of public guarantees for lending to small businesses and family firms, might be desirable to foster family businesses access to finance and economic growth, also during non-crisis periods.

\section{References}

Alessandrini, P., Presbitero, A. F., \& Zazzaro, A. (2008). Banks, distances and firms' financing constraints. Review of Finance, 13(2), 261-307.

Alfani, G., \& Gourdon, V. (2012). Entrepreneurs, formalization of social ties, and trustbuilding in Europe (fourteenth to twentieth centuries). The Economic History Review, 65(3), 1005-1028. Allio, M. K. (2004). Family businesses: Their virtues, vices, and strategic path. Strategy \& Leadership, 32(4), 24-33. 
Amore, M. D., \& Bennedsen, M. (2013). The value of local political connections in a low-corruption environment. Journal of Financial Economics, 110(2), 387-402.

Anderson, R. C., Duru, A., \& Reeb, D. M. (2012). Investment policy in family controlled firms. Journal of Banking \& Finance, 36(6), 1744-1758.

Anderson, R. C., Mansi, S. A., \& Reeb, D. M. (2003). Founding family ownership and the agency cost of debt. Journal of Financial Economics, 68(2), 263-285.

Anderson, R. C., \& Reeb, D. M. (2003). Founding-family ownership and firm performance: evidence from the S\&P 500. The Journal of Finance, 58(3), 1301-1328.

Andres, C. (2011). Family ownership, financing constraints and investment decisions. Applied Financial Economics, 21(22), 1641-1659.

Bandiera, O., Guiso, L., Prat, A., \& Sadun, R. (2015). Matching firms, managers, and incentives. Journal of Labor Economics, 33(3), 623-681.

Benfratello, L., Schiantarelli, F. and Sembenelli, A. (2008). Banks and innovation: microeconometric evidence on Italian firms. Journal of Financial Economics, 90(2), 197217.

Bennedsen, M., Nielsen, K. M., Pérez-González, F., \& Wolfenzon, D. (2007). Inside the family firm: The role of families in succession decisions and performance. The Quarterly Journal of Economics, 122(2), 647-691.

Bertrand, M., \& Schoar, A. (2006). The role of family in family firms. The Journal of Economic Perspectives, 20(2), 73-96.

Bianchi, M., \& Bianco, M. (2008). L'Evoluzione della corporate governance in Italia: Meno piramidi più coalizioni. Il Mulino, Bologna.

Bianco, M. (2003). L'industria italiana (Vol. 89). Il mulino.

Bolton, P., \& Thadden, V. (1998). Blocks, liquidity, and corporate control. The Journal of Finance, $53(1), 1-25$.

Bopaiah, C. (1998). Availability of credit to family businesses. Small Business Economics, 11(1), 75-86.

Braggion, F. (2011). Managers and (secret) social networks: the influence of the Freemasonry on firm performance. Journal of the European Economic Association, 9(6), 1053-1081.

Bunkanwanicha, P., Fan, J. P., \& Wiwattanakantang, Y. (2013). The value of marriage to family firms. Journal of Financial and Quantitative Analysis, 48(2), 611-636. 
Burkart, M., Panunzi, F., \& Shleifer, A. (2003). Family firms. The Journal of Finance, 58(5), 2167-2201.

Carillo, M. R., Lombardo, V., \& Zazzaro, A. (2015). Family firms and entrepreneurial human capital in the process of development (No. 400). Centre for Studies in Economics and Finance (CSEF), University of Naples, Italy.

Claessens, S., Djankov, S., Fan, J. P., \& Lang, L. H. (2002). Disentangling the incentive and entrenchment effects of large shareholdings. The Journal of Finance, 57(6), 2741-2771.

Colli, A. (2012). Contextualizing performances of family firms: The perspective of business history. Family Business Review, 25(3), 243-257.

Cosci, S., Meliciani, V., \& Sabato, V. (2016). Relationship lending and innovation: empirical evidence on a sample of European firms. Economics of Innovation and New Technology, 25(4), 335-357.

Cucculelli, M., \& Micucci, G. (2008). Family succession and firm performance: Evidence from Italian family firms. Journal of Corporate Finance, 14(1), 17-31.

Cucculelli, M., \& Peruzzi, V. (2017). Bank screening technologies and the founder effect: Evidence from European lending relationships. Finance Research Letters, 20, 229-237.

Cucculelli, M., Peruzzi, V., \& Zazzaro, A. (2016). Relational capital in lending relationships: Evidence from European family firms (No. 128). Money and Finance Research group (Mo. Fi. R.) - Univ. Politecnica Marche - Dept. Economic and Social Sciences.

D'Aurizio, L., Oliviero, T., \& Romano, L. (2015). Family firms, soft information and bank lending in a financial crisis. Journal of Corporate Finance, 33, 279-292.

D’Onofrio, A., Minetti, R., \& Murro, P. (2017). Banking development, socioeconomic structure and income inequality. Journal of Economic Behavior \& Organization, forthcoming.

Daily, C. M., \& Dollinger, M. J. (1992). An empirical examination of ownership structure in family and professionally managed firms. Family Business Review, 5(2), 117-136.

Donckels, R., \& Fröhlich, E. (1991). Are family businesses really different? European experiences from STRATOS. Family Business Review, 4(2), 149-160.

Ellul, A., Pagano, M. \& Panunzi, F. (2010). Inheritance law and investment in family firms. American Economic Review, 100(5), 2414-50.

Elsas, R. (2005). Empirical determinants of relationship lending. Journal of Financial Intermediation, 14(1), 32-57. 
Faccio, M. and Lang, L. H. P. (2002). The ultimate ownership of Western European corporations. Journal of Financial Economics, 65(3), 365-95.

Faccio, M., \& Parsley, D. C. (2009). Sudden deaths: Taking stock of geographic ties. Journal of Financial and Quantitative Analysis, 44(3), 683-718.

Ferri, G., \& Murro, P. (2015). Do firm-bank 'odd couples' exacerbate credit rationing?. Journal of Financial Intermediation, 24(2), 231-251.

Ferri, G., Murro, P., Peruzzi, V., \& Rotondi, Z. (2017). Bank lending technologies and credit availability in Europe. What can we learn from the crisis? (No. 135). Money and Finance Research group (Mo. Fi. R.) - Univ. Politecnica Marche - Dept. Economic and Social Sciences.

Fukuyama, F. (1995). Trust: the social virtues and the creation of prosperity. Free Press.

Gambini, A., \& Zazzaro, A. (2013). Long-lasting bank relationships and growth of firms. Small Business Economics, 40(4), 977-1007.

Gedajlovic, E. R., \& Shapiro, D. M. (1998). Management and ownership effects: Evidence from five countries. Strategic Management Journal, 533-553.

Gugler, K. (2003). Corporate governance and investment. International Journal of the Economics of Business, 10(3), 261-289.

Guiso, L., Sapienza, P., \& Zingales, L. (2004). The role of social capital in financial development. The American Economic Review, 94(3), 526-556.

Habbershon, T. G., Williams, M., \& MacMillan, I. C. (2003). A unified systems perspective of family firm performance. Journal of Business Venturing, 18(4), 451-465.

Hung, J. H., \& Kuo, Y. P. (2011). The effect of family control on investment-cash flow sensitivity. Applied Financial Economics, 21(12), 897-904.

Huson, M. R., Parrino, R., \& Starks, L. T. (2001). Internal monitoring mechanisms and CEO turnover: A long-term perspective. The Journal of Finance, 56(6), 2265-2297.

James, H. S. (1999). Owner as manager, extended horizons and the family firm. International Journal of the Economics of Business, 6(1), 41-55.

Jara-Bertin, M., López-Iturriaga, F. J., \& López-de-Foronda, Ó. (2008). The contest to the control in European family firms: How other shareholders affect firm value. Corporate Governance: An International Review, 16(3), 146-159. 
La Porta, R., Lopez-de-Silanes, F., \& Shleifer, A. (1999). Corporate ownership around the world. The Journal of Finance, 54(2), 471-517.

Le Breton-Miller, I., \& Miller, D. (2006). Why do some family businesses out-compete? Governance, long-term orientations, and sustainable capability. Entrepreneurship Theory and Practice, 30(6), 731-746.

Levenson, A. R., \& Willard, K. L. (2000). Do firms get the financing they want? Measuring credit rationing experienced by small businesses in the US. Small Business Economics, 14(2), 83-94.

Liberti, J. M., \& Mian, A. R. (2009). Estimating the effect of hierarchies on information use. The Review of Financial Studies, 22(10), 4057-4090.

Maury, B., \& Pajuste, A. (2005). Multiple large shareholders and firm value. Journal of Banking \& Finance, 29(7), 1813-1834.

Miller, D., Le Breton-Miller, I., \& Scholnick, B. (2008). Stewardship vs. stagnation: An empirical comparison of small family and non-family businesses. Journal of Management Studies, 45(1), 51-78.

Minetti, R., Murro, P., \& Paiella, M. (2015a). Ownership structure, governance, and innovation. European Economic Review, 80, 165-193.

Minetti, R., Murro, P., Rotondi, Z., \& Zhu, S. C. (2017). Financial Constraints, Firms' Supply Chains and Internationalization. Journal of the European Economic Association, forthcoming.

Minetti, R., Murro, P., \& Zhu, S. C. (2015b). Family Firms, Corporate Governance and Export. Economica, 82(1), 1177-1216.

Minetti, R., \& Zhu, S. C. (2011). Credit constraints and firm export: Microeconomic evidence from Italy. Journal of International Economics, 83(2), 109-125.

Morck, R., Shleifer, A., \& Vishny, R. W. (1989). Alternative Mechanisms for Corporate Control. The American Economic Review, 79(4), 842-852.

Morgado, A., \& Pindado, J. (2003). The underinvestment and overinvestment hypotheses: an analysis using panel data. European Financial Management, 9(2), 163-177.

Pan, X., \& Tian, G. G. (2016). Family control and loan collateral: Evidence from China. Journal of Banking \& Finance, 67, 53-68. 
Pavitt, K. (1984). Sectoral patterns of technical change: towards a taxonomy and a theory. Research Policy, 13(6), 343-373.

Perez-Gonzalez, F. (2006). Inherited control and firm performance. The American Economic Review, 96(5), 1559-1588.

Peruzzi, V. (2017). Does family ownership structure affect investment-cash flow sensitivity? Evidence from Italian SMEs. Applied Economics, 49(43), 4378-4393.

Pindado, J., Requejo, I., \& de la Torre, C. (2011). Family control and investment-cash flow sensitivity: Empirical evidence from the Euro zone. Journal of Corporate Finance, 17(5), 1389-1409.

Poza, E. J., Alfred, T., \& Maheshwari, A. (1997). Stakeholder perceptions of culture and management practices in family and family firms-A preliminary report. Family Business Review, 10(2), 135-155.

Presbitero, A. F., \& Zazzaro, A. (2011). Competition and relationship lending: Friends or foes?. Journal of Financial Intermediation, 20(3), 387-413.

Putnam, R. (1993). Making democracy work: civic tradition in modern Italy. Princeton University Press.

Rajan, R. G., \& Zingales, L. (1998). Power in a Theory of the Firm. The Quarterly Journal of Economics, 113(2), 387-432.

Rose, M. B. (2000). Firms, networks and business values: The British and American cotton industries since 1750 (Vol. 8). Cambridge University Press.

Salvato, C., \& Melin, L. (2008). Creating value across generations in Family-Controlled businesses: The role of family social capital. Family Business Review, 21(3), 259-276.

Sraer, D. and Thesmar, D. (2007). Performance and behaviour of family firms: evidence from the French stock market. Journal of the European Economic Association, 5(4), 709-51.

Stacchini, M., \& Degasperi, P. (2015). Trust, family businesses and financial intermediation. Journal of Corporate Finance, 33, 293-316.

Steijvers, T., Voordeckers, W., \& Vanhoof, K. (2010). Collateral, relationship lending and family firms. Small Business Economics, 34(3), 243-259.

Stein, J. C. (1988). Takeover threats and managerial myopia. Journal of Political Economy, 96(1), 61-80. 
Stein, J. C. (1989). Efficient capital markets, inefficient firms: A model of myopic corporate behavior. The Quarterly Journal of Economics, 104(4), 655-669.

Uchida, H., Udell, G. F., \& Yamori, N. (2012). Loan officers and relationship lending to SMEs. Journal of Financial Intermediation, 21(1), 97-122.

The Economist (2015). To have and to hold. 18 April.

Thomsen, S., \& Pedersen, T. (2000). Ownership structure and economic performance in the largest European companies. Strategic Management Journal, 689-705.

Villalonga, B., \& Amit, R. (2006). How do family ownership, control and management affect firm value?. Journal of Financial Economics, 80(2), 385-417.

Voordeckers, W., \& Steijvers, T. (2006). Business collateral and personal commitments in SME lending. Journal of Banking \& Finance, 30(11), 3067-3086.

Wang, D. (2006). Founding family ownership and earnings quality. Journal of Accounting Research, 44(3), 619-656.

Ward, J. (2004). Perpetuating The Family Business. 50 Lessons Learned from Long-Lasting. Successful Families in Business, Basingstoke.

Wooldridge, J. (2002). Econometric analysis of cross section and panel data. The MIT Press, Cambridge, Massachusetts London, England.

World Bank (2012). World development indicators. World Bank, Washington, D.C. 
Figure 1

Credit rationing distribution across Italian provinces.

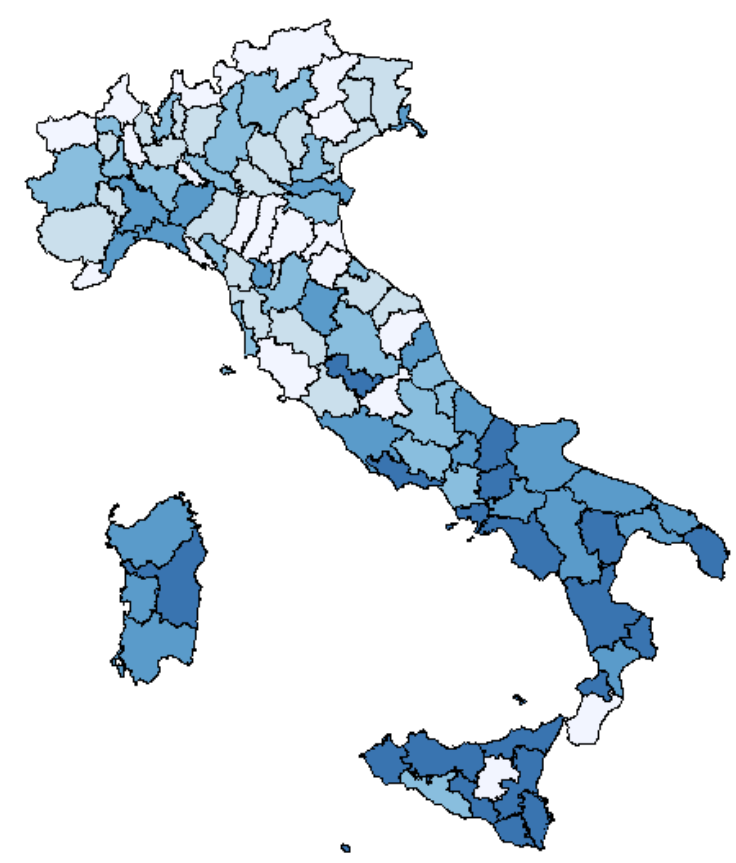

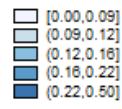

(A) Weak credit rationing

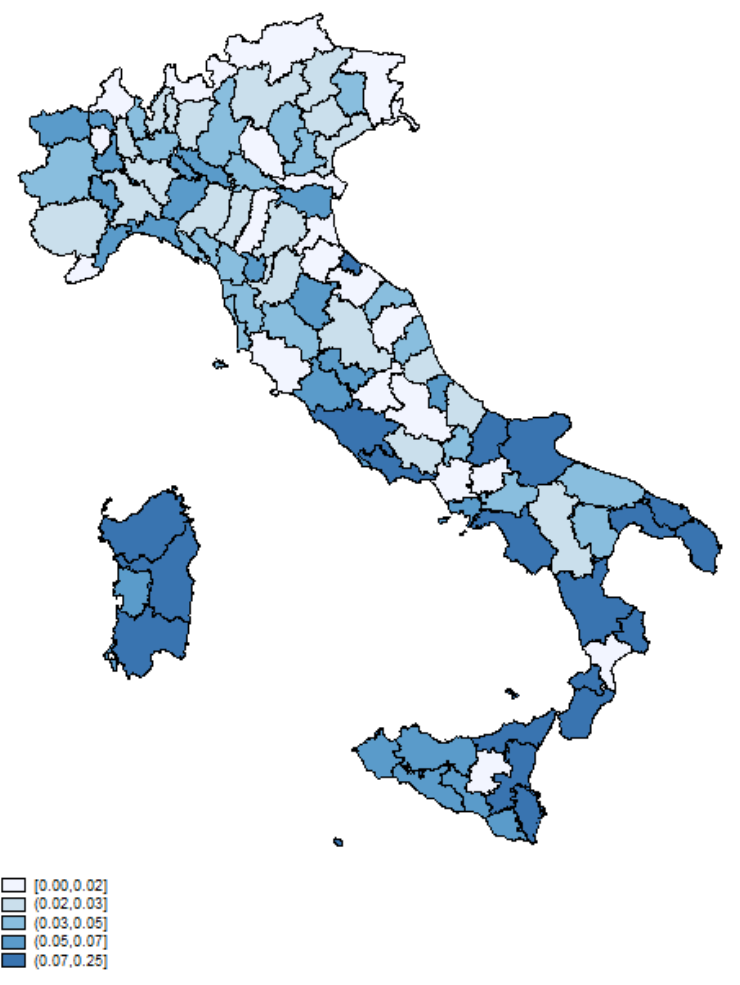

(B) Strong credit rationing 


\section{Table 1}

Variable definitions.

\begin{tabular}{|c|c|}
\hline Variable & Description and source (in parentheses) \\
\hline Weak Rationing & $\begin{array}{l}\text { Dummy that takes the value of one if the firm was weakly rationed in the last year of the survey, } \\
\text { and zero otherwise. (SIMF) }\end{array}$ \\
\hline Strong Rationing & $\begin{array}{l}\text { Dummy that takes the value of one if the firm was strongly rationed in the last year of the survey, } \\
\text { and zero otherwise. (SIMF) }\end{array}$ \\
\hline Family Firm & $\begin{array}{l}\text { Dummy that takes the value of one if the main shareholder is a family or an individual, and zero } \\
\text { otherwise. (SIMF) }\end{array}$ \\
\hline Family Control & $\begin{array}{l}\text { Dummy that takes the value of one if the family owner has the control of the firm, and zero } \\
\text { otherwise. (SIMF) }\end{array}$ \\
\hline Family Firm $20 \%$ & $\begin{array}{l}\text { Dummy that takes the value of one if the main shareholder is a family or an individual and owns } \\
\text { more than } 20 \text { percent of the company, and zero otherwise. (SIMF) }\end{array}$ \\
\hline External Manager & $\begin{array}{l}\text { Dummy that takes the value of one if the CEO is not a member of the family, and zero otherwise. } \\
\text { (SIMF) }\end{array}$ \\
\hline Number of Employees & Total number of employees. (BvD-AIDA) \\
\hline Age & Number of years since firm's inception. (BvD-AIDA) \\
\hline Leverage & Ratio of total liabilities to equity (average over the three years of the survey). (BvD-AIDA) \\
\hline ROI & $\begin{array}{l}\text { Ratio between net income and invested capital (average over the three years of the survey). } \\
\text { (BvD-AIDA) }\end{array}$ \\
\hline Labour Productivity & $\begin{array}{l}\text { Ratio between value added and number of employees (average over the three years of the } \\
\text { survey). (BvD-AIDA) }\end{array}$ \\
\hline Capital Intensity & $\begin{array}{l}\text { Ratio between fixed assets and number of employees (average over the three years of the survey). } \\
\text { (BvD-AIDA) }\end{array}$ \\
\hline Ownership Concentration & Ownership share of the firm's first shareholder. (SIMF) \\
\hline Number of Banks & Number of banks from which the firm borrows. (SIMF) \\
\hline Relationship Length & Length of the relationship with the main bank (in years). (SIMF) \\
\hline Value Added & Average growth rate of provincial value added. (ISTAT) \\
\hline HHI & Provincial Herfindahl index of bank branches. (Bank of Italy) \\
\hline Rajan and Zingales Index & Measure of external financial dependence proposed by Rajan and Zingales (1998). \\
\hline North & $\begin{array}{l}\text { Dummy that takes the value of one if the firm is located in the North of Italy, and zero otherwise. } \\
\text { (SIMF) }\end{array}$ \\
\hline Center & $\begin{array}{l}\text { Dummy that takes the value of one if the firm is located in the Center of Italy, and zero otherwise. } \\
\text { (SIMF) }\end{array}$ \\
\hline South & $\begin{array}{l}\text { Dummy that takes the value of one if the firm is located in the South of Italy, and zero otherwise. } \\
\text { (SIMF) }\end{array}$ \\
\hline $\begin{array}{l}\text { Financial Institution } \\
\text { Subscriber }\end{array}$ & $\begin{array}{l}\text { Dummy that takes the value of one if a financial institution underwrote new shares of the firm in } \\
\text { the three years of the survey, and zero otherwise. (SIMF) }\end{array}$ \\
\hline Other Subscriber & $\begin{array}{l}\text { Dummy that takes the value of one if an institution (different from a financial institution) } \\
\text { underwrote new shares of the firm in the three years of the survey, and zero otherwise. (SIMF) }\end{array}$ \\
\hline Intention to go Public & $\begin{array}{l}\text { Dummy that takes the value of one if the firm plans to go public in the following year, and zero } \\
\text { otherwise. (SIMF) }\end{array}$ \\
\hline
\end{tabular}


Table 2

Summary statistics.

\begin{tabular}{|c|c|c|c|c|c|c|c|c|c|c|c|}
\hline \multirow{2}{*}{ Credit Rationing } & \multicolumn{2}{|l|}{ All firms } & \multicolumn{3}{|l|}{ Ownership } & \multicolumn{3}{|c|}{ Weak Rationing } & \multicolumn{3}{|c|}{ Strong Rationing } \\
\hline & Mean & $\begin{array}{l}\text { Std } \\
\text { Dev. }\end{array}$ & $\begin{array}{l}\text { Family } \\
\text { Owned }\end{array}$ & $\begin{array}{l}\text { Non-Family } \\
\text { Owned }\end{array}$ & t-test & Rationed & $\begin{array}{lr}\text { Non- } & t \\
\text { Rationed } & \\
\end{array}$ & t-test & \multicolumn{2}{|c|}{$\begin{array}{ll}\text { Rationed } & \text { Non- } \\
& \text { Rationed } \\
\end{array}$} & t-test \\
\hline Weak Rationing & 0.132 & 0.339 & 0.135 & 0.125 & -1.602 & & & & & & \\
\hline Strong Rationing & 0.037 & 0.189 & 0.037 & 0.038 & 0.195 & & & & & & \\
\hline \multicolumn{12}{|l|}{ Ownership variables } \\
\hline Family Firm & 0.775 & 0.417 & & & & 0.787 & 0.772 & -1.603 & 0.770 & 0.774 & 0.195 \\
\hline Family Control & 0.722 & 0.448 & & & & 0.739 & 0.718 & -2.088 & 0.726 & 0.720 & -0.289 \\
\hline Family Firm 20\% & 0.710 & 0.454 & & & & 0.725 & 0.708 & -1.586 & 0.712 & 0.710 & -0.099 \\
\hline External Manager & 0.488 & 0.500 & & & & 0.460 & 0.488 & 1.999 & 0.441 & 0.486 & 1.860 \\
\hline \multicolumn{12}{|l|}{ Control variables } \\
\hline Relationship Length & 16.642 & 11.932 & 16.950 & 15.495 & -6.449 & 15.601 & 16.835 & 4.469 & 15.292 & 16.712 & 2.842 \\
\hline Number of Banks & 5.450 & 3.642 & 5.086 & 6.735 & 21.001 & 5.732 & 5.538 & -2.325 & 6.065 & 5.540 & -3.208 \\
\hline Roi & 0.063 & 0.062 & 0.065 & 0.059 & -4.597 & 0.047 & 0.066 & 13.340 & 0.035 & 0.064 & 14.796 \\
\hline Leverage & 8.085 & 11.636 & 8.345 & 7.192 & -5.332 & 10.375 & 7.609 & -9.027 & 13.114 & 7.758 & -8.029 \\
\hline Age & 26.603 & 20.711 & 26.318 & 27.110 & 2.109 & 24.320 & 26.881 & 5.483 & 24.928 & 26.595 & 1.983 \\
\hline Number of Employees & 81.042 & 108.692 & 58.983 & 148.447 & 46.219 & 63.556 & 81.043 & 6.625 & 72.073 & 79.048 & 1.485 \\
\hline Labour Productivity & 5.914 & 3.020 & 6.119 & 5.045 & -22.109 & 4.661 & 5.874 & 20.661 & 4.765 & 5.753 & 9.220 \\
\hline Capital Intensity & 5.326 & 2.963 & 5.425 & 4.825 & -12.078 & 4.420 & 5.277 & 14.155 & 4.631 & 5.182 & 5.090 \\
\hline Ownership Concentration & 0.554 & 0.293 & 0.499 & 0.747 & 46.349 & 0.556 & 0.551 & -0.855 & 0.586 & 0.550 & -3.011 \\
\hline High-Tech Sector & 0.308 & 0.462 & 0.283 & 0.390 & 12.830 & 0.277 & 0.310 & 3.167 & 0.272 & 0.308 & 1.863 \\
\hline Rajan and Zingales Index & 0.364 & 0.314 & 0.355 & 0.392 & 6.249 & 0.352 & 0.364 & 1.753 & 0.338 & 0.364 & 2.019 \\
\hline HHI & 0.074 & 0.028 & 0.073 & 0.074 & 1.864 & 0.078 & 0.073 & -6.351 & 0.077 & 0.074 & -2.307 \\
\hline Value Added & 0.040 & 0.029 & 0.040 & 0.038 & -3.771 & 0.039 & 0.040 & 2.569 & 0.039 & 0.040 & 0.869 \\
\hline North & 0.683 & 0.465 & 0.670 & 0.723 & 6.464 & 0.579 & 0.695 & 10.338 & 0.579 & 0.684 & 5.155 \\
\hline Center & 0.182 & 0.386 & 0.189 & 0.161 & -4.099 & 0.195 & 0.183 & -1.352 & 0.199 & 0.184 & -0.927 \\
\hline South & 0.135 & 0.342 & 0.141 & 0.116 & -4.278 & 0.226 & 0.122 & -11.106 & 0.222 & 0.132 & -5.254 \\
\hline
\end{tabular}


Table 3

Baseline estimates.

\begin{tabular}{|c|c|c|c|c|c|c|}
\hline \multirow[t]{2}{*}{ Probit Model } & \multicolumn{3}{|c|}{ Weak Rationing } & \multicolumn{3}{|c|}{ Strong Rationing } \\
\hline & $(1)$ & (2) & (3) & (4) & $(5)$ & $(6)$ \\
\hline Family Firm & $\begin{array}{r}0.020^{* * * *} \\
(0.008)\end{array}$ & & & $\begin{array}{r}0.008 * * \\
(0.004)\end{array}$ & & \\
\hline Family Control & & $\begin{array}{r}0.022 * * * \\
(0.007)\end{array}$ & & & $\begin{array}{r}0.007 * * \\
(0.004)\end{array}$ & \\
\hline Family Firm $20 \%$ & & & $\begin{array}{l}0.013^{*} \\
(0.007)\end{array}$ & & & $\begin{array}{l}0.007 * \\
(0.004)\end{array}$ \\
\hline Size & $\begin{array}{r}-0.026 * * * \\
(0.004)\end{array}$ & $\begin{array}{r}-0.026^{* * *} \\
(0.004)\end{array}$ & $\begin{array}{r}-0.027 * * * \\
(0.004)\end{array}$ & $\begin{array}{r}-0.006^{* * * *} \\
(0.002)\end{array}$ & $\begin{array}{r}-0.006^{* * * *} \\
(0.002)\end{array}$ & $\begin{array}{r}-0.006 * * * \\
(0.002)\end{array}$ \\
\hline Age & $\begin{array}{r}0.002 \\
(0.005)\end{array}$ & $\begin{array}{r}0.002 \\
(0.005)\end{array}$ & $\begin{array}{r}0.002 \\
(0.005)\end{array}$ & $\begin{array}{r}0.000 \\
(0.002)\end{array}$ & $\begin{array}{r}-0.000 \\
(0.002)\end{array}$ & $\begin{array}{r}0.000 \\
(0.002)\end{array}$ \\
\hline Leverage & $\begin{array}{r}0.002 * * * \\
(0.000)\end{array}$ & $\begin{array}{r}0.002 * * * \\
(0.000)\end{array}$ & $\begin{array}{r}0.002 * * * \\
(0.000)\end{array}$ & $\begin{array}{r}0.001 * * * \\
(0.000)\end{array}$ & $\begin{array}{r}0.001 * * * \\
(0.000)\end{array}$ & $\begin{array}{r}0.001 * * * \\
(0.000)\end{array}$ \\
\hline ROI & $\begin{array}{r}-0.374 * * * \\
(0.055)\end{array}$ & $\begin{array}{r}-0.370 * * * \\
(0.055)\end{array}$ & $\begin{array}{r}-0.372 * * * \\
(0.056)\end{array}$ & $\begin{array}{r}-0.230 * * * \\
(0.025)\end{array}$ & $\begin{array}{r}-0.229 * * * \\
(0.025)\end{array}$ & $\begin{array}{r}-0.231 * * * \\
(0.025)\end{array}$ \\
\hline Labour Productivity & $\begin{array}{r}-0.045^{* * * *} \\
(0.007)\end{array}$ & $\begin{array}{r}-0.045^{* * * *} \\
(0.007)\end{array}$ & $\begin{array}{r}-0.046 * * * \\
(0.007)\end{array}$ & $\begin{array}{r}-0.012 * * * \\
(0.003)\end{array}$ & $\begin{array}{r}-0.012 * * * \\
(0.003)\end{array}$ & $\begin{array}{r}-0.012 * * * \\
(0.003)\end{array}$ \\
\hline Capital Intensity & $\begin{array}{r}0.013 * * * \\
(0.004)\end{array}$ & $\begin{array}{r}0.013 * * * \\
(0.004)\end{array}$ & $\begin{array}{r}0.013 * * * \\
(0.004)\end{array}$ & $\begin{array}{r}0.005 * * * \\
(0.002)\end{array}$ & $\begin{array}{r}0.005 * * * \\
(0.002)\end{array}$ & $\begin{array}{r}0.005 * * * \\
(0.002)\end{array}$ \\
\hline Ownership Concentration & $\begin{array}{r}0.029 * * \\
(0.013)\end{array}$ & $\begin{array}{c}0.028 * * \\
(0.012)\end{array}$ & $\begin{array}{l}0.021 * \\
(0.012)\end{array}$ & $\begin{array}{c}0.013 * * \\
(0.006)\end{array}$ & $\begin{array}{r}0.011 * * \\
(0.006)\end{array}$ & $\begin{array}{l}0.010^{*} \\
(0.006)\end{array}$ \\
\hline Number Banks & $\begin{array}{r}0.006 * * * \\
(0.001)\end{array}$ & $\begin{array}{r}0.006 * * * \\
(0.001)\end{array}$ & $\begin{array}{r}0.006 * * * \\
(0.001)\end{array}$ & $\begin{array}{r}0.002 * * * \\
(0.000)\end{array}$ & $\begin{array}{r}0.002 * * * \\
(0.000)\end{array}$ & $\begin{array}{r}0.002 * * * \\
(0.000)\end{array}$ \\
\hline Relationship Length & $\begin{array}{r}-0.008 * * \\
(0.004)\end{array}$ & $\begin{array}{r}-0.008 * * \\
(0.004)\end{array}$ & $\begin{array}{r}-0.008 * * \\
(0.004)\end{array}$ & $\begin{array}{r}-0.002 \\
(0.001)\end{array}$ & $\begin{array}{r}-0.002 \\
(0.001)\end{array}$ & $\begin{array}{r}-0.002 \\
(0.001)\end{array}$ \\
\hline Value Added & $\begin{array}{r}-0.177 \\
(0.170)\end{array}$ & $\begin{array}{r}-0.182 \\
(0.162)\end{array}$ & $\begin{array}{r}-0.178 \\
(0.170)\end{array}$ & $\begin{array}{r}-0.050 \\
(0.082)\end{array}$ & $\begin{array}{r}-0.047 \\
(0.082)\end{array}$ & $\begin{array}{r}-0.050 \\
(0.083)\end{array}$ \\
\hline HHI & $\begin{array}{r}0.183 \\
(0.130)\end{array}$ & $\begin{array}{r}0.185 \\
(0.130)\end{array}$ & $\begin{array}{r}0.184 \\
(0.130)\end{array}$ & $\begin{array}{r}-0.011 \\
(0.053)\end{array}$ & $\begin{array}{r}-0.008 \\
(0.053)\end{array}$ & $\begin{array}{r}-0.010 \\
(0.053)\end{array}$ \\
\hline Rajan-Zingales & $\begin{array}{r}0.034 * * \\
(0.016)\end{array}$ & $\begin{array}{c}0.031 * \\
(0.017)\end{array}$ & $\begin{array}{r}0.034 * * \\
(0.016)\end{array}$ & $\begin{array}{r}-0.002 \\
(0.008)\end{array}$ & $\begin{array}{c}-0.002 \\
(0.008)\end{array}$ & $\begin{array}{r}-0.003 \\
(0.008)\end{array}$ \\
\hline North & $\begin{array}{r}-0.065 * * * \\
(0.009)\end{array}$ & $\begin{array}{r}-0.067 * * * \\
(0.009)\end{array}$ & $\begin{array}{r}-0.065 * * * \\
(0.009)\end{array}$ & $\begin{array}{r}-0.009 * * \\
(0.004)\end{array}$ & $\begin{array}{r}-0.010 * * \\
(0.004)\end{array}$ & $\begin{array}{r}-0.009 * * \\
(0.004)\end{array}$ \\
\hline Center & $\begin{array}{r}-0.045^{* * * *} \\
(0.010)\end{array}$ & $\begin{array}{r}-0.046^{* * * *} \\
(0.010)\end{array}$ & $\begin{array}{r}-0.045 * * * \\
(0.011)\end{array}$ & $\begin{array}{r}-0.004 \\
(0.006)\end{array}$ & $\begin{array}{r}-0.005 \\
(0.006)\end{array}$ & $\begin{array}{r}-0.004 \\
(0.006)\end{array}$ \\
\hline Observations & 11,403 & 11,339 & 11,403 & 11,410 & 11,344 & 11,410 \\
\hline Pseudo $\mathrm{R}^{2}$ & 0.073 & 0.073 & 0.072 & 0.089 & 0.088 & 0.088 \\
\hline
\end{tabular}

Notes: The table reports marginal effects. Three, two and one star (*) mean, respectively, a 99, 95, and 90 percent level of significance. Robust standard errors are in parentheses. All of the variables are defined in Table 1. Balance-sheet indicators refer to the survey three-year period. The variable Size is in logarithm. The variable Relationship Length is in logarithm. All regressions include industry and survey dummies, not reported for reasons of space. 
Table 4

Family ownership and agency conflicts.

\begin{tabular}{|c|c|c|c|c|c|c|}
\hline \multirow{3}{*}{$\begin{array}{l}\text { Panel A: } \\
\text { Weak Rationing }\end{array}$} & \multirow{3}{*}{$\begin{array}{l}\text { Own. Conc. } \\
\text { I Quartile } \\
(1)\end{array}$} & \multirow{3}{*}{$\begin{array}{l}\text { Own. Conc. } \\
\text { II Quartile } \\
\text { (2) }\end{array}$} & \multirow{3}{*}{$\begin{array}{l}\text { Own. Conc. } \\
\text { III Quartile } \\
(3)\end{array}$} & \multirow{3}{*}{$\begin{array}{l}\text { Own. Conc. } \\
\text { IV Quartile } \\
(4)\end{array}$} & \multirow{3}{*}{$\begin{array}{l}2^{\text {nd }} \\
\text { Blockholder } \\
(5)\end{array}$} & \multirow{3}{*}{$\begin{array}{l}\text { No } 2^{\text {nd }} \\
\text { Blockholder } \\
(6)\end{array}$} \\
\hline & & & & & & \\
\hline & & & & & & \\
\hline Family Firm & $\begin{array}{l}0.032 * \\
(0.019)\end{array}$ & $\begin{array}{r}0.019 \\
(0.020)\end{array}$ & $\begin{array}{r}0.004 \\
(0.015)\end{array}$ & $\begin{array}{l}0.023 * \\
(0.013)\end{array}$ & $\begin{array}{r}0.013 \\
(0.017)\end{array}$ & $\begin{array}{r}0.028 * * \\
(0.011)\end{array}$ \\
\hline + Control Variables & yes & yes & yes & yes & yes & yes \\
\hline Observations & 2,477 & 1,922 & 3,844 & 3,118 & 5,628 & 4,891 \\
\hline Pseudo $\mathrm{R}^{2}$ & 0.084 & 0.068 & 0.085 & 0.086 & 0.078 & 0.069 \\
\hline
\end{tabular}

\begin{tabular}{|c|c|c|c|c|c|c|}
\hline \multirow{3}{*}{$\begin{array}{l}\text { Panel B: } \\
\text { Strong Rationing }\end{array}$} & \multirow{3}{*}{$\begin{array}{l}\text { Own. Conc. } \\
\text { I Quartile } \\
(1)\end{array}$} & \multirow{3}{*}{$\begin{array}{l}\text { Own. Conc. } \\
\text { II Quartile } \\
(2)\end{array}$} & \multirow{3}{*}{$\begin{array}{l}\text { Own. Conc. } \\
\text { III Quartile } \\
(3)\end{array}$} & \multirow{3}{*}{$\begin{array}{l}\text { Own. Conc. } \\
\text { IV Quartile } \\
(4)\end{array}$} & \multirow{3}{*}{$\begin{array}{l}2^{\text {nd }} \\
\text { Blockholder } \\
(5)\end{array}$} & \multirow{3}{*}{$\begin{array}{l}\text { No } 2^{\text {nd }} \\
\text { Blockholder } \\
(6)\end{array}$} \\
\hline & & & & & & \\
\hline & & & & & & \\
\hline Family Firm & $\begin{array}{l}0.009 * \\
(0.005)\end{array}$ & $\begin{array}{r}0.001 \\
(0.010)\end{array}$ & $\begin{array}{r}-0.003 \\
(0.008)\end{array}$ & $\begin{array}{r}0.018 * * \\
(0.007)\end{array}$ & $\begin{array}{r}0.003 \\
(0.007)\end{array}$ & $\begin{array}{r}0.016^{* * *} \\
(0.006)\end{array}$ \\
\hline + Control Variables & yes & yes & yes & yes & yes & yes \\
\hline Observations & 2,390 & 1,833 & 3,720 & 3,047 & 5,613 & 4,782 \\
\hline Pseudo $\mathrm{R}^{2}$ & 0.121 & 0.145 & 0.115 & 0.095 & 0.105 & 0.090 \\
\hline
\end{tabular}

Notes: The table reports Probit marginal effects. Three, two and one star (*) mean, respectively, a 99, 95, and 90 percent level of significance. Robust standard errors are in parentheses. In columns (1)-(4), Ownership Concentration is the ownership share of the first controlling shareholder. In columns (5)-(6), $2^{\text {nd }}$ Blockholder is a dummy variable equal to one if the second shareholder holds an ownership share larger than 25 percent, and zero otherwise. All regressions include control variables, industry, geographical and survey dummies, not reported for reasons of space. 
Table 5

Family ownership, lack of competencies and conservatism.

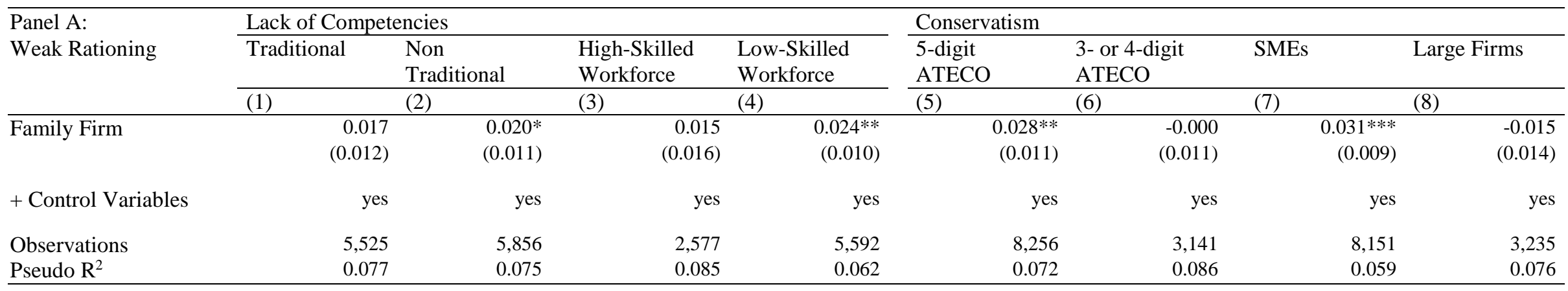

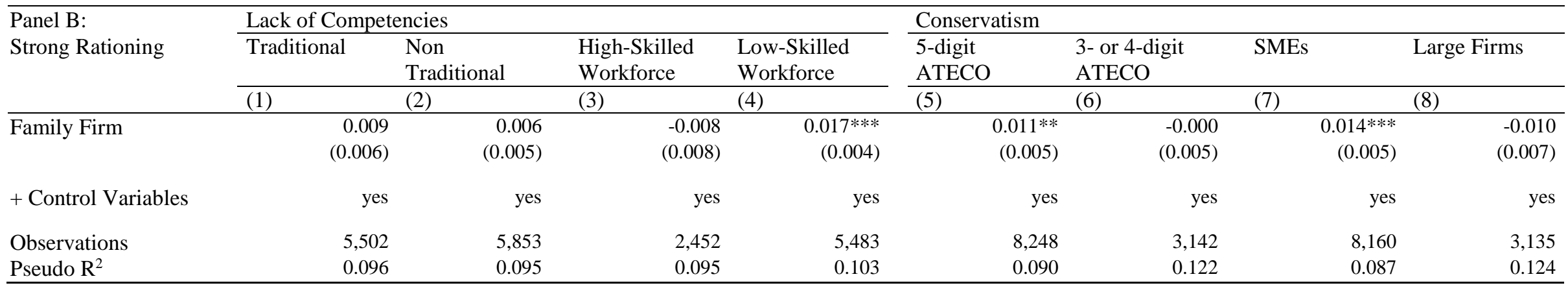

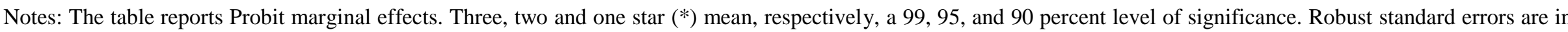

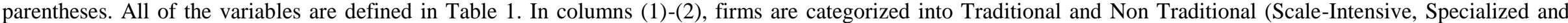

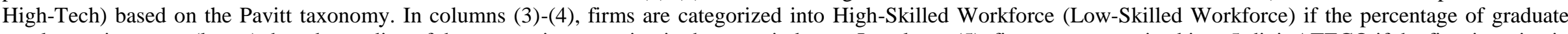

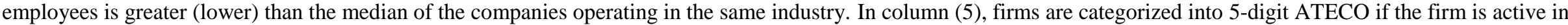

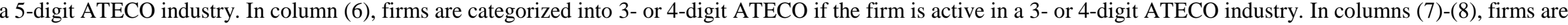

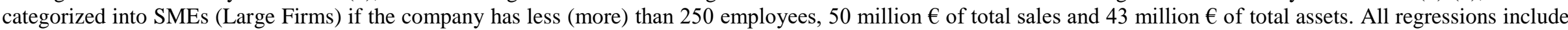
industry, geographical and survey dummies, not reported for reasons of space. 
Table 6

Family ownership, long termism and risk aversion.

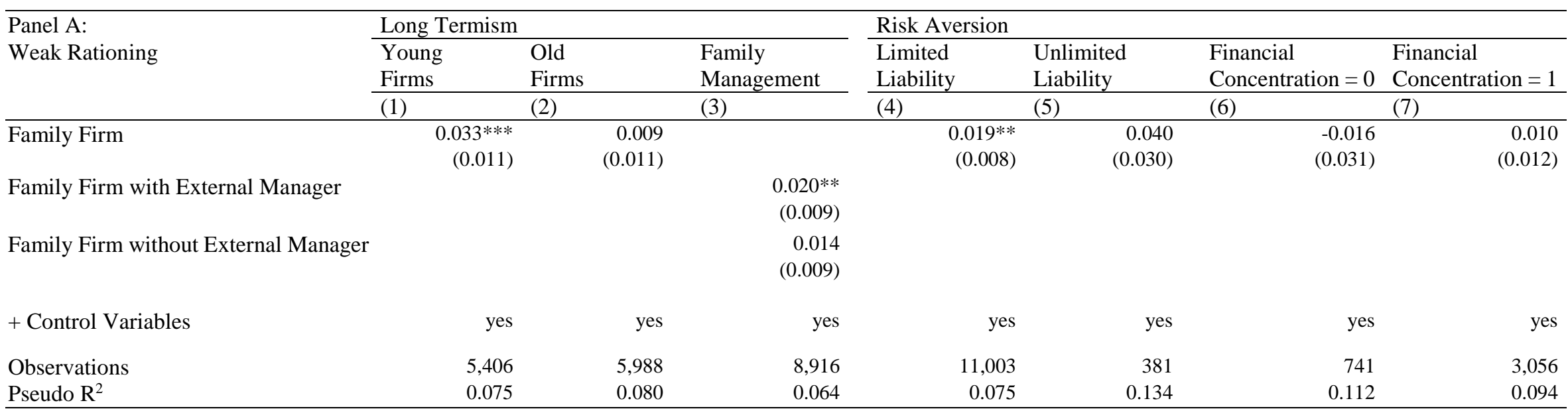

\begin{tabular}{|c|c|c|c|c|c|c|c|}
\hline \multirow{4}{*}{$\begin{array}{l}\text { Panel B: } \\
\text { Strong Rationing }\end{array}$} & \multicolumn{3}{|l|}{ Long Termism } & \multicolumn{4}{|l|}{ Risk Aversion } \\
\hline & Young & Old & Family & Limited & Unlimited & Financial & Financial \\
\hline & Firms & Firms & Management & Liability & Liability & Concentration $=0$ & Concentration $=1$ \\
\hline & (1) & (2) & (3) & (4) & (5) & (6) & (7) \\
\hline Family Firm & $\begin{array}{r}0.013^{* *} \\
(0.006)\end{array}$ & $\begin{array}{r}0.004 \\
(0.005)\end{array}$ & & $\begin{array}{r}0.008^{* *} \\
(0.004)\end{array}$ & $\begin{array}{r}-0.018 \\
(0.021)\end{array}$ & $\begin{array}{l}-0.001 \\
(0.010)\end{array}$ & $\begin{array}{r}0.003 \\
(0.006)\end{array}$ \\
\hline Family Firm with External Manager & & & $\begin{array}{r}0.007 \\
(0.005)\end{array}$ & & & & \\
\hline Family Firm without External Manager & & & $\begin{array}{r}0.007 \\
(0.005)\end{array}$ & & & & \\
\hline + Control Variables & yes & yes & yes & yes & yes & yes & yes \\
\hline Observations & 5,412 & 5,989 & 8,918 & 11,009 & 299 & 599 & 2,921 \\
\hline Pseudo $\mathrm{R}^{2}$ & 0.094 & 0.109 & 0.089 & 0.093 & 0.158 & 0.194 & 0.146 \\
\hline
\end{tabular}

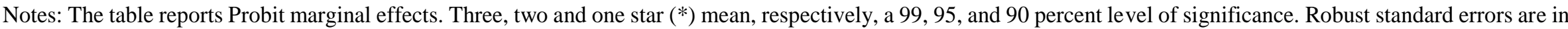

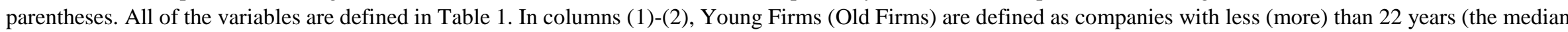

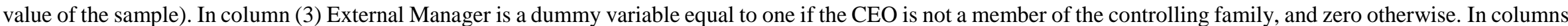

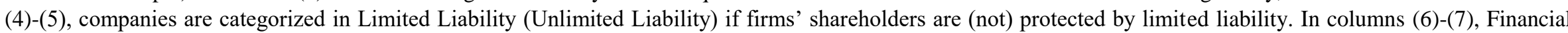

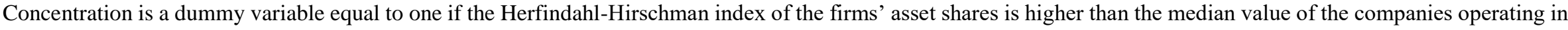
the same industry, and zero otherwise. All regressions include industry, geographical and survey dummies, not reported for reasons of space. 
Table 7

Family ownership and relationship lending.

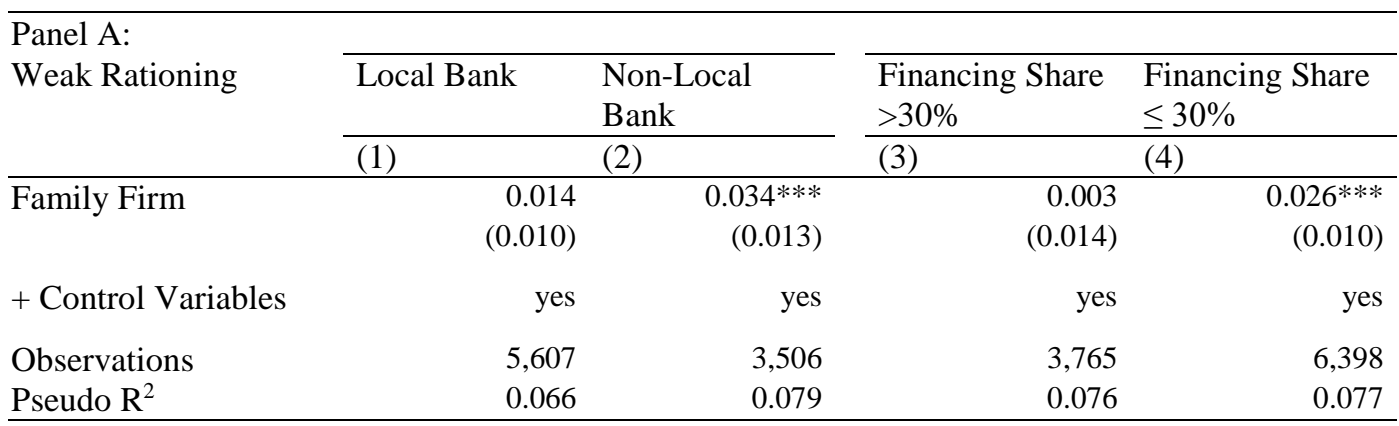

\begin{tabular}{|c|c|c|c|c|}
\hline \multirow{3}{*}{$\begin{array}{l}\text { Panel B: } \\
\text { Strong Rationing }\end{array}$} & \multirow[b]{2}{*}{ Local Bank } & \multirow[b]{2}{*}{$\begin{array}{l}\text { Non-Local } \\
\text { Bank }\end{array}$} & \multirow[b]{2}{*}{$\begin{array}{l}\text { Financing Share } \\
>30 \%\end{array}$} & \multirow[b]{2}{*}{$\begin{array}{l}\text { Financing Share } \\
\leq 30 \%\end{array}$} \\
\hline & & & & \\
\hline & (1) & (2) & (3) & (4) \\
\hline Family Firm & $\begin{array}{r}0.001 \\
(0.005)\end{array}$ & $\begin{array}{r}0.020^{* * * *} \\
(0.007)\end{array}$ & $\begin{array}{r}0.006 \\
(0.007)\end{array}$ & $\begin{array}{r}0.009^{* *} \\
(0.004)\end{array}$ \\
\hline + Control Variables & yes & yes & yes & yes \\
\hline Observations & 5,613 & 3,434 & 3,638 & 6,397 \\
\hline Pseudo $\mathrm{R}^{2}$ & 0.095 & 0.109 & 0.086 & 0.099 \\
\hline
\end{tabular}

Notes: The table reports Probit marginal effects. Three, two and one star (*) mean, respectively, a 99, 95, and 90 percent level of significance. Robust standard errors are in parentheses. All of the variables are defined in Table 1. In columns (1)-(2), firms are categorized as having a Local Bank (Non-Local Bank) if the firm's main bank is (not) located in the same province of the company. In columns (3)-(4), Financing Share is the share of the firm's main bank financing (30 percent is the median value of the sample). All regressions include industry, geographical and survey dummies, not reported for reasons of space. 
Table 8

Family ownership and socio-economic conditions.

\begin{tabular}{|c|c|c|c|c|c|c|c|c|}
\hline \multirow{3}{*}{$\begin{array}{l}\text { Panel A: } \\
\text { Weak Rationed }\end{array}$} & \multicolumn{4}{|c|}{ Social Capital } & \multicolumn{2}{|c|}{ Socio-economic development } & \multicolumn{2}{|c|}{ Judicial efficiency } \\
\hline & $\begin{array}{l}\text { High Blood } \\
\text { Donation }\end{array}$ & $\begin{array}{l}\text { Low Blood } \\
\text { Donation }\end{array}$ & $\begin{array}{l}\text { High Voter } \\
\text { Turnout }\end{array}$ & $\begin{array}{l}\text { Low Voter } \\
\text { Turnout }\end{array}$ & $\begin{array}{l}\text { North and } \\
\text { Center }\end{array}$ & South & $\begin{array}{l}\text { Length of } \\
\text { Processes } \\
<346 \text { days }\end{array}$ & $\begin{array}{l}\text { Length of } \\
\text { Processes } \\
\geq 346 \text { days }\end{array}$ \\
\hline & (1) & (2) & (3) & (4) & (5) & (6) & (7) & (8) \\
\hline Family Firm & $\begin{array}{r}0.027 * * \\
(0.011)\end{array}$ & $\begin{array}{r}0.011 \\
(0.010)\end{array}$ & $\begin{array}{r}0.031 * * * \\
(0.011)\end{array}$ & $\begin{array}{r}0.007 \\
(0.009)\end{array}$ & $\begin{array}{r}0.019 * * \\
(0.008)\end{array}$ & $\begin{array}{r}0.018 \\
(0.030)\end{array}$ & $\begin{array}{r}0.023^{* *} \\
(0.010)\end{array}$ & $\begin{array}{r}0.016 \\
(0.010)\end{array}$ \\
\hline + Control Variables & yes & yes & yes & yes & yes & yes & yes & yes \\
\hline Observations & 6,182 & 5,208 & 5,607 & 5,782 & 9,760 & 1,630 & 4,820 & 4,820 \\
\hline Pseudo $\mathrm{R}^{2}$ & 0.083 & 0.065 & 0.0842 & 0.0681 & 0.090 & 0.068 & 0.080 & 0.080 \\
\hline
\end{tabular}

\begin{tabular}{|c|c|c|c|c|c|c|c|c|}
\hline \multirow{2}{*}{$\begin{array}{l}\text { Panel B: } \\
\text { Strong Rationed }\end{array}$} & \multicolumn{4}{|c|}{ Social Capital } & \multicolumn{2}{|c|}{ Socio-economic development } & \multicolumn{2}{|c|}{ Judicial efficiency } \\
\hline & $\begin{array}{l}\text { High Blood } \\
\text { Donation }\end{array}$ & $\begin{array}{l}\text { Low Blood } \\
\text { Donation }\end{array}$ & $\begin{array}{l}\text { High Voter } \\
\text { Turnout }\end{array}$ & $\begin{array}{l}\text { Low Voter } \\
\text { Turnout }\end{array}$ & $\begin{array}{l}\text { North and } \\
\text { Center }\end{array}$ & South & $\begin{array}{l}\text { Length of } \\
\text { Processes } \\
<346 \text { days }\end{array}$ & $\begin{array}{l}\text { Length of } \\
\text { Processes } \\
>346 \text { davs }\end{array}$ \\
\hline Family Firm & $\begin{array}{r}0.015 * * * \\
(0.006)\end{array}$ & $\begin{array}{r}0.000 \\
(0.005)\end{array}$ & $\begin{array}{r}0.014 * * \\
(0.006)\end{array}$ & $\begin{array}{r}0.001 \\
(0.004)\end{array}$ & $\begin{array}{l}0.007 * \\
(0.004)\end{array}$ & $\begin{array}{r}0.013 \\
(0.016)\end{array}$ & $\begin{array}{r}0.008 \\
(0.005)\end{array}$ & $\begin{array}{r}0.008 \\
(0.005)\end{array}$ \\
\hline + Control Variables & yes & yes & yes & yes & yes & yes & yes & yes \\
\hline Observations & 6,155 & 5,215 & 5,611 & 5,769 & 9,738 & 1,532 & 4,770 & 6,550 \\
\hline Pseudo $\mathrm{R}^{2}$ & 0.093 & 0.109 & 0.090 & 0.111 & 0.105 & 0.087 & 0.105 & 0.093 \\
\hline
\end{tabular}

Notes: The table reports Probit marginal effects. Three, two and one star (*) mean, respectively, a 99, 95, and 90 percent level of significance. Robust standard errors are in parentheses. All of the variables are defined in Table 1. In columns (1)-(2), firms are categorized as located in provinces with High Blood Donation (Low Blood Donation) if the number of blood bags per million inhabitants collected by AVIS (the Italian association of blood donors) is more (less) than 0.035 (he median value of the sample). In columns (3)-(4), firms are categorized as located in provinces with High Voter Turnout (Low Voter Turnout) if the voter turnout for all the referenda before 1989 is more (less) than 86 percent (the median value of the sample). In columns (5)-(6), provinces north of Florence are located in the North, provinces between Florence and Rome are located in the Center, and provinces south of Rome are in the South. In columns (7)-(8), Length of Processes is the number of days it takes to complete a first-degree trial by the courts located in a province (364 days is the median value of the sample). All regressions include industry, geographical and survey dummies, not reported for reasons of space. 
Table 9

Endogeneity issues.

\begin{tabular}{|c|c|c|c|c|c|c|c|c|c|}
\hline \multirow[t]{4}{*}{ Probit Model } & \multicolumn{3}{|c|}{ Selection Equation } & \multicolumn{6}{|c|}{ Principal Equation } \\
\hline & \multirow{3}{*}{$\begin{array}{l}\text { Family } \\
\text { Firm } \\
(1)\end{array}$} & \multirow{3}{*}{$\begin{array}{l}\text { Family } \\
\text { Control } \\
(2)\end{array}$} & \multirow{3}{*}{$\begin{array}{l}\text { Family } \\
\text { Firm 20\% } \\
(3)\end{array}$} & \multicolumn{3}{|c|}{ Weak Rationing } & \multicolumn{3}{|c|}{ Strong Rationing } \\
\hline & & & & & & & & & \\
\hline & & & & (4) & (5) & (6) & $(7)$ & $(8)$ & (9) \\
\hline Financial Inst. Subscriber & $\begin{array}{r}-0.056 \\
(0.043)\end{array}$ & $\begin{array}{l}-0.086^{*} \\
(0.046)\end{array}$ & $\begin{array}{r}-0.099 * * \\
(0.048)\end{array}$ & & & & & & \\
\hline Other Subscriber & $\begin{array}{r}-0.082 * * \\
(0.038)\end{array}$ & $\begin{array}{r}-0.077 * \\
(0.040)\end{array}$ & $\begin{array}{r}-0.083^{*} \\
(0.045)\end{array}$ & & & & & & \\
\hline Intention to go public & $\begin{array}{r}0.010 \\
(0.028)\end{array}$ & $\begin{array}{r}0.029 \\
(0.031)\end{array}$ & $\begin{array}{r}0.017 \\
(0.032)\end{array}$ & & & & & & \\
\hline Family Firm & & & & $\begin{array}{r}0.015 * * \\
(0.007)\end{array}$ & & & $\begin{array}{l}0.006^{*} \\
(0.004)\end{array}$ & & \\
\hline Family Control & & & & & $\begin{array}{r}0.019 * * * \\
(0.007)\end{array}$ & & & $\begin{array}{c}0.007 * \\
(0.004)\end{array}$ & \\
\hline Family Firm $20 \%$ & & & & & & $\begin{array}{l}0.013 * \\
(0.007)\end{array}$ & & & $\begin{array}{l}0.007 * \\
(0.004)\end{array}$ \\
\hline Size & $\begin{array}{r}-0.123 * * * \\
(0.005)\end{array}$ & $\begin{array}{r}-0.137 * * * \\
(0.005)\end{array}$ & $\begin{array}{r}-0.156 * * * \\
(0.006)\end{array}$ & $\begin{array}{r}-0.005 \\
(0.006)\end{array}$ & $\begin{array}{r}0.005 \\
(0.009)\end{array}$ & $\begin{array}{r}0.012 \\
(0.012)\end{array}$ & $\begin{array}{r}0.002 \\
(0.004)\end{array}$ & $\begin{array}{r}0.004 \\
(0.004)\end{array}$ & $\begin{array}{r}0.004 \\
(0.006)\end{array}$ \\
\hline Age & $\begin{array}{r}0.043 * * * \\
(0.007)\end{array}$ & $\begin{array}{r}0.034 * * * \\
(0.008)\end{array}$ & $\begin{array}{r}0.033 * * * \\
(0.010)\end{array}$ & $\begin{array}{r}-0.004 \\
(0.006)\end{array}$ & $\begin{array}{r}-0.005 \\
(0.006)\end{array}$ & $\begin{array}{r}-0.005 \\
(0.006)\end{array}$ & $\begin{array}{l}-0.003 \\
(0.002)\end{array}$ & $\begin{array}{r}-0.003 \\
(0.002)\end{array}$ & $\begin{array}{l}-0.002 \\
(0.002)\end{array}$ \\
\hline Leverage & $\begin{array}{r}0.000 \\
(0.000)\end{array}$ & $\begin{array}{r}0.000 \\
(0.000)\end{array}$ & $\begin{array}{r}0.000 \\
(0.001)\end{array}$ & $\begin{array}{r}0.002 * * * * \\
(0.000)\end{array}$ & $\begin{array}{r}0.002 * * * \\
(0.000)\end{array}$ & $\begin{array}{r}0.002 * * * \\
(0.000)\end{array}$ & $\begin{array}{r}0.001 * * * * \\
(0.000)\end{array}$ & $\begin{array}{r}0.001 * * * \\
(0.000)\end{array}$ & $\begin{array}{r}0.001 * * * \\
(0.000)\end{array}$ \\
\hline ROI & $\begin{array}{r}0.643 * * * \\
(0.082)\end{array}$ & $\begin{array}{r}0.769 * * * \\
(0.086)\end{array}$ & $\begin{array}{r}0.854 * * * \\
(0.094)\end{array}$ & $\begin{array}{r}-0.436 * * * \\
(0.067)\end{array}$ & $\begin{array}{r}-0.486 * * * \\
(0.075)\end{array}$ & $\begin{array}{r}-0.525 * * * \\
(0.088)\end{array}$ & $\begin{array}{r}-0.248 * * * \\
(0.028)\end{array}$ & $\begin{array}{r}-0.261 * * * \\
(0.032)\end{array}$ & $\begin{array}{r}-0.261 * * * \\
(0.035)\end{array}$ \\
\hline Labour Productivity & $\begin{array}{r}-0.146^{* * * *} \\
(0.012)\end{array}$ & $\begin{array}{r}-0.162 * * * \\
(0.014)\end{array}$ & $\begin{array}{r}-0.161 * * * \\
(0.014)\end{array}$ & $\begin{array}{r}-0.027 * * * * \\
(0.009)\end{array}$ & $\begin{array}{r}-0.017 \\
(0.011)\end{array}$ & $\begin{array}{r}-0.014 \\
(0.013)\end{array}$ & $\begin{array}{l}-0.005 \\
(0.003)\end{array}$ & $\begin{array}{r}-0.003 \\
(0.004)\end{array}$ & $\begin{array}{r}-0.004 \\
(0.005)\end{array}$ \\
\hline Capital Intensity & $\begin{array}{l}-0.003 \\
(0.005)\end{array}$ & $\begin{array}{l}-0.001 \\
(0.005)\end{array}$ & $\begin{array}{r}-0.004 \\
(0.005)\end{array}$ & $\begin{array}{r}0.015 * * * \\
(0.004)\end{array}$ & $\begin{array}{r}0.015 * * * \\
(0.004)\end{array}$ & $\begin{array}{r}0.016 * * * \\
(0.004)\end{array}$ & $\begin{array}{r}0.006 * * * \\
(0.002)\end{array}$ & $\begin{array}{r}0.006 * * * \\
(0.002)\end{array}$ & $\begin{array}{r}0.006^{* * * *} \\
(0.002)\end{array}$ \\
\hline Ownership Concentration & $\begin{array}{r}-0.432 * * * \\
(0.015)\end{array}$ & $\begin{array}{r}-0.318^{* * * *} \\
(0.021)\end{array}$ & $\begin{array}{r}-0.064 * * * \\
(0.024)\end{array}$ & $\begin{array}{r}0.088 * * * \\
(0.027)\end{array}$ & $\begin{array}{r}0.092 * * * \\
(0.028)\end{array}$ & $\begin{array}{r}0.038 * * * \\
(0.014)\end{array}$ & $\begin{array}{r}0.034 * * \\
(0.014)\end{array}$ & $\begin{array}{r}0.031 * * \\
(0.012)\end{array}$ & $\begin{array}{r}0.013 * * \\
(0.007)\end{array}$ \\
\hline Number Banks & $\begin{array}{r}0.002 \\
(0.001)\end{array}$ & $\begin{array}{r}0.004 * * * \\
(0.001)\end{array}$ & $\begin{array}{r}0.005^{* * * *} \\
(0.002)\end{array}$ & $\begin{array}{r}0.006^{* * * *} \\
(0.001)\end{array}$ & $\begin{array}{r}0.005^{* * * *} \\
(0.001)\end{array}$ & $\begin{array}{r}0.005 * * * \\
(0.001)\end{array}$ & $\begin{array}{r}0.002 * * * \\
(0.000)\end{array}$ & $\begin{array}{r}0.002 * * * \\
(0.000)\end{array}$ & $\begin{array}{r}0.002 * * * \\
(0.000)\end{array}$ \\
\hline Relationship Length & $\begin{array}{r}0.012 * * \\
(0.006)\end{array}$ & $\begin{array}{r}0.014 * * \\
(0.006)\end{array}$ & $\begin{array}{r}0.015^{* *} \\
(0.006)\end{array}$ & $\begin{array}{r}-0.010 * * \\
(0.004)\end{array}$ & $\begin{array}{r}-0.011 * * * \\
(0.004)\end{array}$ & $\begin{array}{r}-0.012 * * * \\
(0.004)\end{array}$ & $\begin{array}{c}-0.002 * \\
(0.001)\end{array}$ & $\begin{array}{r}-0.003 * * \\
(0.001)\end{array}$ & $\begin{array}{c}-0.003 * \\
(0.001)\end{array}$ \\
\hline Value Added & $\begin{array}{r}-0.202 \\
(0.163)\end{array}$ & $\begin{array}{r}-0.190 \\
(0.197)\end{array}$ & $\begin{array}{r}-0.218 \\
(0.194)\end{array}$ & $\begin{array}{r}-0.158 \\
(0.183)\end{array}$ & $\begin{array}{r}-0.151 \\
(0.174)\end{array}$ & $\begin{array}{r}-0.139 \\
(0.183)\end{array}$ & $\begin{array}{l}-0.045 \\
(0.087)\end{array}$ & $\begin{array}{r}-0.039 \\
(0.086)\end{array}$ & $\begin{array}{c}-0.042 \\
(0.087)\end{array}$ \\
\hline HHI & $\begin{array}{r}-0.178 \\
(0.158)\end{array}$ & $\begin{array}{l}-0.308 \\
(0.196)\end{array}$ & $\begin{array}{r}-0.335^{*} \\
(0.203)\end{array}$ & $\begin{array}{r}0.154 \\
(0.137)\end{array}$ & $\begin{array}{r}0.190 \\
(0.135)\end{array}$ & $\begin{array}{r}0.202 \\
(0.137)\end{array}$ & $\begin{array}{r}-0.007 \\
(0.054)\end{array}$ & $\begin{array}{r}0.007 \\
(0.054)\end{array}$ & $\begin{array}{r}0.003 \\
(0.054)\end{array}$ \\
\hline Rajan-Zingales & $\begin{array}{r}0.034 \\
(0.025)\end{array}$ & $\begin{array}{r}0.033 \\
(0.025)\end{array}$ & $\begin{array}{r}0.064 * * \\
(0.028)\end{array}$ & $\begin{array}{l}0.030^{*} \\
(0.018)\end{array}$ & $\begin{array}{r}0.025 \\
(0.019)\end{array}$ & $\begin{array}{r}0.020 \\
(0.018)\end{array}$ & $\begin{array}{r}-0.002 \\
(0.008)\end{array}$ & $\begin{array}{r}-0.002 \\
(0.008)\end{array}$ & $\begin{array}{c}-0.004 \\
(0.008)\end{array}$ \\
\hline Inverse Mills Ratio & & & & $\begin{array}{r}-0.087 * * * \\
(0.029)\end{array}$ & $\begin{array}{r}-0.132 * * * \\
(0.044)\end{array}$ & $\begin{array}{r}-0.150 * * * \\
(0.052)\end{array}$ & $\begin{array}{r}-0.033 * * \\
(0.016)\end{array}$ & $\begin{array}{r}-0.043 * * \\
(0.020)\end{array}$ & $\begin{array}{l}-0.038 \\
(0.024)\end{array}$ \\
\hline Observations & 11,092 & 11,035 & 11,094 & 10,944 & 10,887 & 10,944 & 10,956 & 10,893 & 10,956 \\
\hline Pseudo $\mathrm{R}^{2}$ & 0.262 & 0.176 & 0.137 & 0.073 & 0.073 & 0.073 & 0.091 & 0.090 & 0.090 \\
\hline
\end{tabular}

Notes: The table reports marginal effects. Three, two and one star (*) mean, respectively, a 99, 95, and 90 percent level of significance. Robust standard errors are in parentheses. All of the variables are defined in Table 1. Balance-sheet indicators refer to the survey three-year period. The variable Size is in logarithm. The variable Relationship Length is in logarithm. All regressions include industry and survey dummies, not reported for reasons of space. 